PII S0016-7037(00)00848-1

\title{
Enhanced regeneration of phosphorus during formation of the most recent eastern Mediterranean sapropel (S1)
}

\author{
Caroline P. Slomp, ${ }^{1}$ John Thomson, ${ }^{2}$ and Gert J. De Lange ${ }^{1}$ \\ ${ }^{1}$ Department of Geochemistry, Faculty of Earth Sciences, Utrecht University, P.O. Box 80021, 3508 TA Utrecht, the Netherlands \\ ${ }^{2}$ Southampton Oceanography Centre, Empress Dock, Southampton, United Kingdom
}

(Received May 4, 2001; accepted in revised form October 2, 2001)

\begin{abstract}
Phosphorus regeneration and burial fluxes during and after formation of the most recent sapropel S1 were determined for two deep-basin, low-sedimentation sites in the eastern Mediterranean Sea. Organic $\mathrm{C} / \mathrm{P}$ ratios and burial fluxes indicate enhanced regeneration of $\mathrm{P}$ relative to $\mathrm{C}$ during deposition of sapropel $\mathrm{S} 1$. This is largely due to the enhanced release of $\mathrm{P}$ from organic matter during sulfate reduction. Release of $\mathrm{P}$ from $\mathrm{Fe}$-bound $\mathrm{P}$ also increased, but this was only a relatively minor source of dissolved $\mathrm{P}$. Pore-water $\mathrm{HPO}_{4}^{2-}$ concentrations remained too low for carbonate fluorapatite formation. An increased burial of biogenic Ca-P (i.e., fish debris) was observed for one site. Estimated benthic fluxes of $\mathrm{P}$ during sapropel formation were elevated relative to the present day $\left(\sim 900\right.$ to 2800 vs. $\sim 70$ to $\left.120 \mu \mathrm{mol} \mathrm{m}^{-2} \mathrm{yr}^{-1}\right)$. The present-day sedimentary $\mathrm{P}$ cycle in the deep-basin sediments is characterized by two major zones of reaction: (1) the zone near the sediment-water interface where substantial release of $\mathrm{HPO}_{4}^{2-}$ from organic matter takes place, and (2) the oxidation front at the top of the $\mathrm{S} 1$ where upward-diffusing $\mathrm{HPO}_{4}^{2-}$ from below the sapropel is sorbed to Fe-oxides. The efficiency of aerobic organisms in retaining $\mathrm{P}$ is reflected in the low organic $\mathrm{C} / \mathrm{P}$ ratios in the oxidized part of the sapropel. Burial efficiencies for reactive $\mathrm{P}$ were significantly lower during $\mathrm{S} 1$ times compared with the present day ( $\sim 7$ to $15 \%$ vs. 64 to $77 \%$ ). Budget calculations for the eastern Mediterranean Sea demonstrate that the weakening of the antiestuarine circulation and the enhanced regeneration of $\mathrm{P}$ both contributed to a significant increase in deep-water $\mathrm{HPO}_{4}^{2-}$ concentrations during sapropel S1 times. Provided that sufficient vertical mixing occurred, enhanced regeneration of $\mathrm{P}$ at the seafloor may have played a key role in maintaining increased productivity during sapropel S1 formation. Copyright @ 2002 Elsevier Science Ltd
\end{abstract}

\section{INTRODUCTION}

Eastern Mediterranean Sea sediments consist of an alternation of organic-poor hemipelagic layers and organic-rich sapropel units. The formation of these sapropels is most likely due to the combined effect of increased surface water productivity and improved preservation of organic matter under anoxic bottom-water conditions (Calvert et al., 1992; Rohling, 1994; Passier et al., 1999; Thomson et al., 1999). The episodes of increased productivity were presumably initiated by a climate-induced increase in the continental runoff of freshwater carrying nutrients (Rossignol-Strick et al., 1982; Hilgen, 1991). This enhanced input of low-salinity water led to a weakening of the antiestuarine water circulation (Rohling, 1994) or to a circulation reversal (Sarmiento et al., 1988; Thunell and Williams, 1989) in the basin and, as a consequence, to a decreased ventilation of the deep water with oxygen.

At present, phosphorus $(\mathrm{P})$ is the limiting nutrient in the eastern Mediterranean Sea (Berland et al., 1980; Krom et al., 1991). This means that changes in the biogeochemical cycle of $\mathrm{P}$ linked to changes in deep-water oxygenation may have played a key role during times of sapropel formation. Enhanced regeneration of $\mathrm{P}$ relative to $\mathrm{C}$ can be the result of redoxdependent release of $\mathrm{P}$ from organic matter (Gächter et al., 1988; Ingall et al., 1993; Van Cappellen and Ingall, 1994) and Fe-oxides (Einsele, 1936; Mortimer, 1941). In sediments accumulating under $\mathrm{O}_{2}$-depleted bottom water, this is reflected in

* Author to whom correspondence should be addressed (slomp@geo.uu.nl). low ratios of the organic $\mathrm{C}$ decomposition rate to dissolved $\mathrm{P}$ flux and a reduced burial of reactive $\mathrm{P}$ relative to organic $\mathrm{C}$ in the sediment, as has been demonstrated for a number of modern and ancient lacustrine and marine environments (e.g., Ingall and Jahnke, 1994, 1997; Van Cappellen and Ingall, 1994; Arthur and Dean, 1998; Schenau and de Lange, 2001). The mechanism for enhanced mineralization of $\mathrm{P}$ from organic matter under anoxia is still incompletely understood and has been questioned by some (e.g., Colman et al., 1997; McManus et al., 1997; Colman and Holland, 2000). Furthermore, enhanced release of $\mathrm{P}$ from organic matter and $\mathrm{Fe}$ oxides in anoxic environments may partly be counteracted by an increased burial of other reactive $\mathrm{P}$ forms, such as authigenic calcium phosphate minerals (Ingall et al., 1993; Van Cappellen and Ingall, 1994, 1996; Schenau et al., 2000) and phosphatic fish debris, here referred to as biogenic Ca-P (DeVries and Pearcy, 1982; Schenau and de Lange, 2000).

Despite the potential importance of redox-related changes in $P$ regeneration efficiency, this process is not included in current models of sapropel formation. For example, in recent model calculations of nutrient cycling and thermohaline circulation in sapropel times, Stratford et al. (2000) assumed that remineralization of both $\mathrm{C}$ and $\mathrm{P}$ is slower under anoxia when compared with oxic conditions. This situation may at least be partly due to the limited and contradictory reports on $\mathrm{P}$ in sapropels and its diagenetic alteration. Pruysers et al. (1991) reported total P enrichments in sapropel S1, S5, and S6 for a site near Crete and attributed this entirely to organic matter assuming a Redfield organic C/P molar ratio of 106. Eijsink et al. (1997), in contrast, observed an organic $\mathrm{C} / \mathrm{P}$ ratio in sapropel $\mathrm{S} 1$ of $\sim 400$. This 


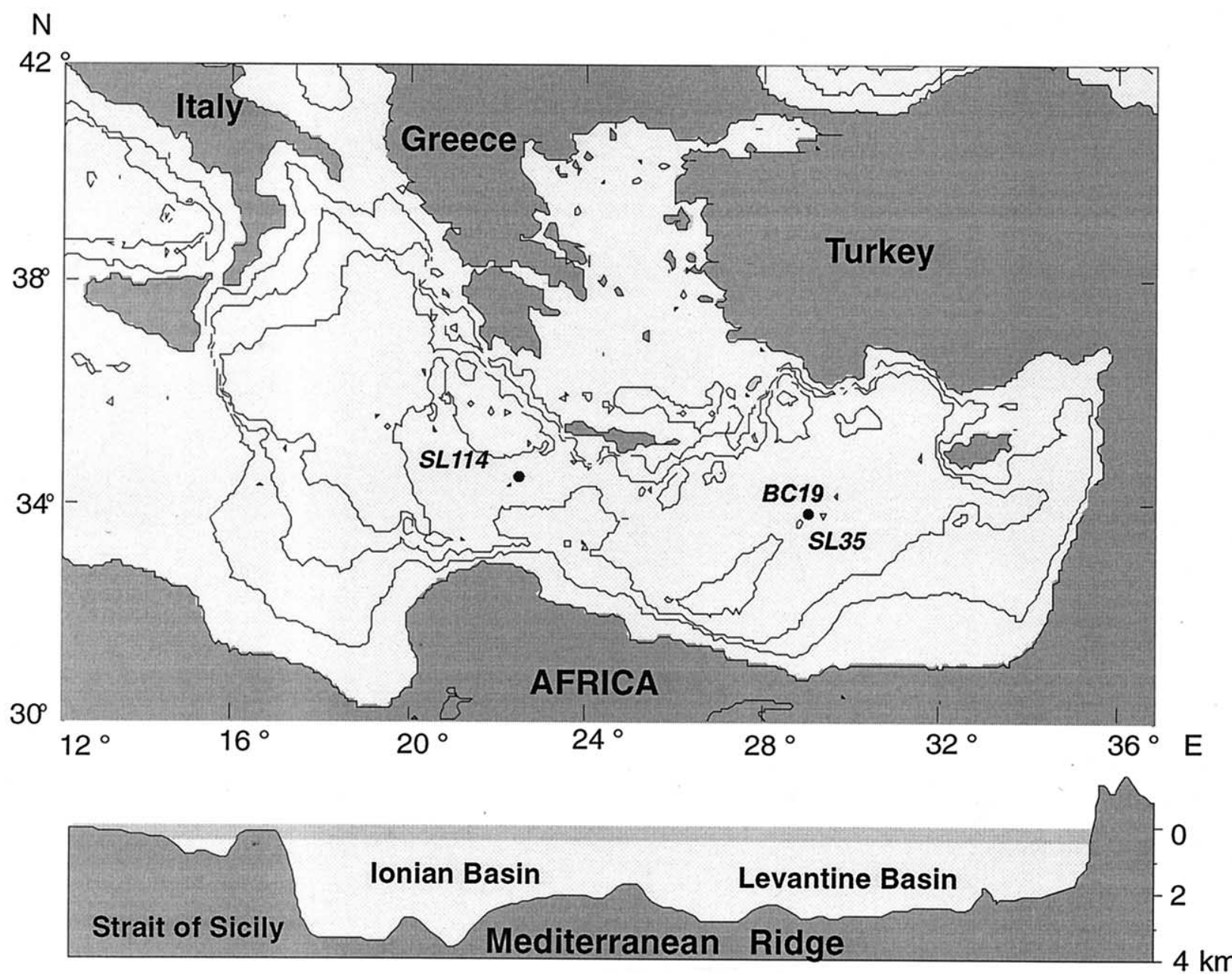

Fig. 1. Sample locations of the three box cores studied. SL35 is at $33^{\circ} 47.776^{\prime} \mathrm{N}, 28^{\circ} 36.613^{\prime} \mathrm{E}, 2765 \mathrm{~m}$; BC19 is at $33^{\circ} 47.85^{\prime} \mathrm{N} 28^{\circ} 36.50^{\prime} \mathrm{E}, 2750 \mathrm{~m}$; SL114 is at $35^{\circ} 17.241^{\prime} \mathrm{N}, 21^{\circ} 24.519^{\prime} \mathrm{E}, 3390 \mathrm{~m}$.

latter value is in line with the enhanced regeneration hypothesis. P enrichments above sapropel S1 have been suggested to be associated with Fe-oxides formed by diagenetic processes after sapropel formation (Thomson et al., 1995).

In this article, we use high-resolution pore-water and solidphase data for two low-sedimentation rate, deep-basin sites in the eastern Mediterranean Sea to determine whether there is indeed evidence for a reduced burial (i.e., enhanced regeneration) of reactive $\mathrm{P}$ relative to organic $\mathrm{C}$ during the formation of the most recent sapropel S1 (also termed Si2, Lourens et al., 1996) between 6.0 and $9.5 \mathrm{kyr}$ BP (radiocarbon convention years; Mercone et al., 2000). In addition, we determine whether increased burial of authigenic calcium $\mathrm{P}$, biogenic $\mathrm{Ca}-\mathrm{P}$, or both occurs in sapropel $\mathrm{S} 1$ and elucidate the diagenetic reactions affecting $\mathrm{P}$ during and after sapropel formation. Finally, the potential role of benthic $\mathrm{P}$ regeneration in sapropel $\mathrm{S} 1$ formation in the eastern Mediterranean is discussed.

\section{MATERIALS AND METHODS}

\subsection{Sampling}

Three box cores from two locations in the central part of the eastern Mediterranean Sea (Fig. 1) were selected for this study.
Box core BC19 was recovered during the Marflux-I MD69 cruise of the RV Marion Dufresnein 1991. Box cores SL35 (BC19 site) and SL114 were obtained during the Medineth cruise of the RV Logachevin 1999. The BC19 site was revisited in 1999 to obtain pore-water data to complement the solidphase data collected for the original BC19 core. Subsamples were taken from the box cores with acrylic liners $(10 \mathrm{~cm}$ inner diameter). Only cores without visible disturbance were used. Bottom-water samples were obtained from the overlying water in the box cores with a syringe and subsequently filtered (Acrodisc polysulfone filters, $0.2 \mu \mathrm{m}$ ).

\subsection{Pore-Water Analyses}

Subcores were sliced at in situ temperature $\left(13^{\circ} \mathrm{C}\right)$ in a nitrogen-filled glovebox immediately after collection. Pore water for cores SL35 and SL114 was collected by centrifugation of sediment in disposable polypropylene tubes $(15 \mathrm{~min}, 4400 \mathrm{~g}$ ) and subsequent filtration of the overlying water (Acrodisc polysulfone filters, $0.2 \mu \mathrm{m}$ ). All pore-water samples were split into several portions under nitrogen. Subsamples for $\mathrm{HPO}_{4}^{2-}$, $\mathrm{Fe}$ and $\mathrm{Mn}$ analyses were acidified to $\mathrm{pH} \approx 1$ (with $12 \mathrm{~mol} / \mathrm{L}$ 
$\mathrm{HCl})$. The samples were immediately analyzed for $\mathrm{NO}_{3}^{-}, \mathrm{NH}_{4}^{+}$ and $\mathrm{HPO}_{4}^{2-}$ on board with a Technicon TRAACS-800 autoanalyzer (Grasshoff, 1983). Precision was generally better than $1.5 \%$ for $\mathrm{NO}_{3}^{-}, 3 \%$ for $\mathrm{NH}_{4}^{+}$, and $1 \%$ for $\mathrm{HPO}_{4}^{2-}$. Diluted pore-water samples $(10 \times)$ were analyzed for total $\mathrm{Fe}$ (only core SL114) and Mn in Utrecht with a Perkin-Elmer $4100 \mathrm{ZL}$ Zeeman AAS. All samples were analyzed in triplicate. Precision was generally better than $5 \%$ for $\mathrm{Fe}$ and $4 \%$ for $\mathrm{Mn}$.

\subsection{Solid-Phase Analyses}

Sediment samples $(0.5-\mathrm{cm}$ depth resolution) from cores BC19 and SL114 were freeze-dried and ground in an agate mortar. Water contents were calculated from the weight loss on drying. Total concentrations of $\mathrm{Al}, \mathrm{S}, \mathrm{Ba}, \mathrm{Mn}$, and $\mathrm{P}$ were determined after digestion in a mixture of $\mathrm{HF}, \mathrm{HNO}_{3}$, and $\mathrm{HClO}_{4}$ and final solution in $1 \mathrm{~mol} / \mathrm{L} \mathrm{HCl}$ via ICP-OES (PerkinElmer Optima 3000). The accuracy of the measurements was monitored by including laboratory standards. The error in the analysis was $<5 \%$ for all elements. Organic $\mathrm{C}$ was determined on a Fisons Instruments CNS NA 1500 analyzer. Inorganic C was removed before the analysis by shaking the sample with 1 $\mathrm{mol} / \mathrm{L} \mathrm{HCl}$ twice $(12 \mathrm{~h}$ and $4 \mathrm{~h}$ ). The sample was then rinsed with demineralized water twice, freeze dried, and ground in an agate mortar. Tests showed that the amount of organic $\mathrm{C}$ hydrolyzed by the $\mathrm{HCl}$ treatment was negligible. The error in the analysis was less than $1 \%$.

Two sequential extraction procedures for $\mathrm{P}$ were used. All extractions were performed in duplicate. In the first procedure, which was modified from that of Ruttenberg (1992) by Slomp et al. (1996), inorganic sediment P in 14 to 16 selected samples from box cores BC19 and SL114 was fractionated into Febound $\mathrm{P}$, authigenic + biogenic Ca-P, and detrital Ca-P. Febound $\mathrm{P}$ was determined as the sum of the $\mathrm{P}$ extracted with

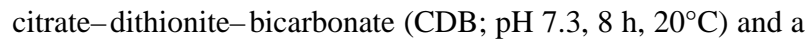
subsequent wash step with $1 \mathrm{M} \mathrm{MgCl}_{2}$. The sediment residue was then rinsed with $1 \mathrm{~mol} / \mathrm{L} \mathrm{Na-acetate}$ buffer $(\mathrm{pH} 4,6 \mathrm{~h}$, $20^{\circ} \mathrm{C}$ ) and a $1 \mathrm{~mol} / \mathrm{L} \mathrm{MgCl}_{2}$ wash solution. Authigenic + biogenic Ca-P was calculated as the sum of the $\mathrm{P}$ extracted in these last two steps. The sediment residue was then treated with $1 \mathrm{~mol} / \mathrm{L} \mathrm{HCl}\left(24 \mathrm{~h}, 20^{\circ} \mathrm{C}\right)$, and the amount of extracted $\mathrm{P}$ was used as a measure of detrital Ca-P. Organic P was determined nonsequentially as the difference between total $\mathrm{P}$ and $1 \mathrm{~mol} / \mathrm{L}$ $\mathrm{HCl}$ extractable $\mathrm{P}(24 \mathrm{~h})$. Inorganic $\mathrm{P}$ concentrations determined as the sum of Fe-bound $\mathrm{P}$, authigenic $\mathrm{P}$, and detrital Ca-P were approximately equal to $\mathrm{P}$ concentrations obtained with $1 \mathrm{~mol} / \mathrm{L} \mathrm{HCl}$ in the one-step procedure.

In the second sequential extraction procedure, repeated 2 mol/ $/ \mathrm{NH}_{4} \mathrm{Cl}$ rinses $\left(8 \times, \mathrm{pH} 7,4 \mathrm{~h}, 20^{\circ} \mathrm{C}\right)$ were included before the $\mathrm{CDB}$ extraction to quantify biogenic Ca-P (Schenau and de Lange, 2000) for 12 selected samples from core BC19. The sediment residue was subsequently treated with the full sequential extraction procedure. Comparison of the results of the two sequential extraction procedures showed an increase in $\mathrm{CDB}$ extractable $\mathrm{P}$ and an equivalent decrease in the sum of authigenic + biogenic Ca-P when including the $\mathrm{NH}_{4} \mathrm{Cl}$ stepthat is, when the second procedure was used. This was attributed to readsorption of $\mathrm{HPO}_{4}^{2-}$ released during the $\mathrm{NH}_{4} \mathrm{Cl}$ extraction to sediment particles and subsequent extraction with the CDB solution. To circumvent this problem, biogenic $\mathrm{P}$ concentrations were calculated as the difference between acetate extractable $\mathrm{Ca}-\mathrm{P}$ determined in the first and second sequential extraction procedure (i.e., biogenic $\mathrm{Ca}-\mathrm{P}=$ authigenic + biogenic Ca-P minus authigenic $\mathrm{Ca}-\mathrm{P}$ ).

Fish debris was quantified in sieve samples (1-cm resolution; 150 - to $500-\mu \mathrm{m}$ fraction) from core BC19 and SL114 by counting the number of fish fragments in a split of the sieve fraction for each depth interval. The number of fish fragments per weight of total sediment in that interval was then calculated from the weight of the split, the weight of the sieve fraction, and the total weight of the sediment for each interval.

The $\mathrm{P}$ and $\mathrm{Fe}$ concentrations in the $\mathrm{CDB}$ solutions were measured via ICP-OES (Spectro Analytical Instruments). $\mathrm{CDB}$-extractable $\mathrm{Fe}$ is assumed to be a measure of total $\mathrm{Fe}$ bound in Fe oxides (Slomp et al., 1996). All other P analyses were carried out with a Perkin-Elmer spectrophotometer with the method of Strickland and Parsons (1972). The precision of the individual $\mathrm{P}$ extractions was generally $\sim 5 \%$, with the exception of the CDB step $(\sim 10 \%)$.

For core $\mathrm{BC} 19$, AMS ${ }^{14} \mathrm{C}$ dating of foraminiferal samples (Globigerinoides ruber) from four sediment depths was performed (Van der Borg et al., 1987). Ages in radiocarbon convention years BP were converted to calibrated ages assuming a constant reservoir age of $402 \mathrm{yr}$ (Stuiver et al., 1998).

\section{RESULTS}

\subsection{General Sediment Geochemistry}

In both cores BC19 and SL114, the dark-colored visual sapropel is characterized by higher $\mathrm{C}_{\text {org }}(1$ to $4 \%)$ and $\mathrm{S}(\sim 0.5$ to $5 \%$ ) concentrations than the surrounding sediment (Fig. 2). Depth profiles of $\mathrm{Ba}$ show a gaussian-shaped increase starting at the base of the sapropel and returning to baseline values at $\sim 5.5 \mathrm{~cm}$ above the top of the visual sapropel in both cores. Porosity profiles follow the general trend observed for Ba. Enrichments of $\mathrm{Mn}$ and $\mathrm{Fe}$ are found above the visual sapropel. Both cores contain an ash layer. In core BC19, the ash layer is located at $10.5 \mathrm{~cm}$ and is identified as being from the Minoan eruption of Santorini at $3.6 \mathrm{kyr}$ BP (Bruins and Van der Plicht, 1996). In core SL114, the source of the ash layer located at 6.4 $\mathrm{cm}$ remains unidentified as it appears to be too young to be from Santorini.

\subsection{Pore-Water Profiles}

Pore-water profiles for cores SL35 (BC19 site) and SL114 are very similar (Fig. 3). $\mathrm{NO}_{3}^{-}$concentrations in the surface sediment are high and decrease almost linearly to the top of the visual sapropel. Here, $\mathrm{NO}_{3}^{-}$is removed, probably through denitrification, to a constant background level of $\sim 0.3$ to 0.5 $\mu \mathrm{M}$. Profiles of $\mathrm{NH}_{4}^{+}, \mathrm{Fe}^{2+}, \mathrm{Mn}^{2+}$, and $\mathrm{HPO}_{4}^{2-}$ indicate upward diffusion from below the sapropel and removal at or near the top of the visual sapropel. Only in the case of $\mathrm{HPO}_{4}^{2-}$ as this removal is not complete, and an upward flux into the overlying sediment is maintained.

\subsection{Solid-Phase $P$ Forms}

The solid-phase profiles of P in both cores BC19 and SL114 show the same general trends (Fig. 4). Total P concentrations 


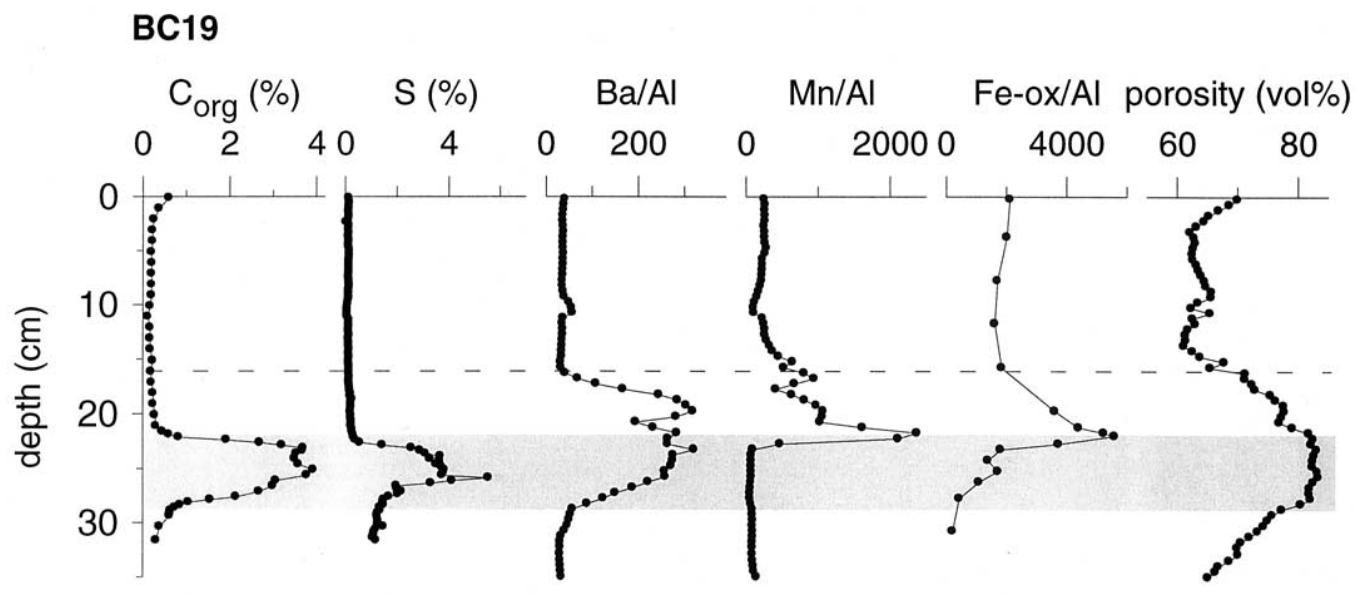

\section{SL114}

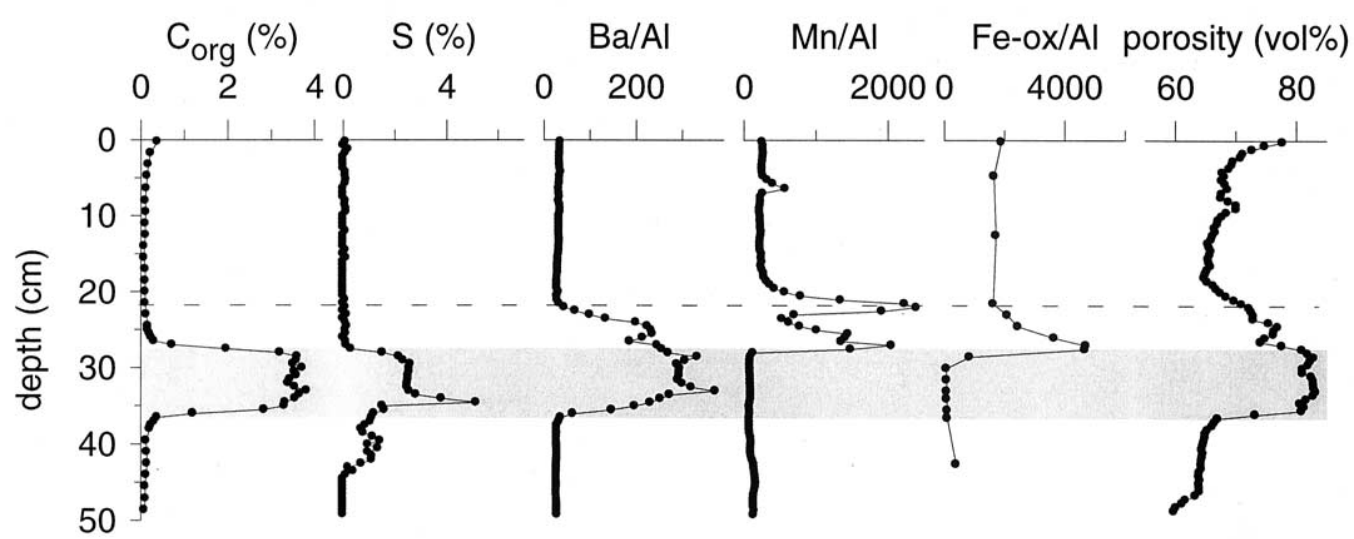

Fig. 2. Depth profiles of organic $\mathrm{C}(\%), \mathrm{S}(\%), \mathrm{Ba} / \mathrm{Al}, \mathrm{Mn} / \mathrm{Al}$, and Fe-oxide $\mathrm{Fe} / \mathrm{Al}$ (ppm/\%) and porosity (vol\%) for cores $\mathrm{BC} 19$ and SL114. The visual S1 sapropel is indicated by the shaded area. The top of the original sapropel is marked with a dotted line. $\mathrm{Ba}, \mathrm{Mn}$, and $\mathrm{Fe}$ profiles are normalized to $\mathrm{Al}$ to correct for fluctuations in carbonate content.

are relatively constant at $\sim 11$ to $13 \mu \mathrm{mol} / \mathrm{g}$ in the upper part of the core. $\mathrm{P}$ enrichments at the top of the visual sapropel consist almost completely of Fe-bound P. Organic P concentrations in the sapropel are equal to or slightly higher than in the surrounding sediment. In core $\mathrm{BC} 19$, the visual sapropel is locally enriched in authigenic + biogenic Ca-P. In core SL114, slight enrichments in this reactive Ca-P form are observed above and in the visual sapropel. Detrital P concentrations are low, and apart from slightly lower concentrations in the visual sapropel, they show little variation with depth.

Further fractionation of the authigenic and biogenic $\mathrm{P}$ for core $\mathrm{BC} 19$ shows that the peaks in authigenic and biogenic $\mathrm{P}$ can be totally attributed to biogenic Ca-P (Fig. 5). The positions of the maxima in (authigenic + ) biogenic $\mathrm{P}$ coincide with the positions of the maxima in the number of fish debris fragments per gram for both sites. The relative magnitude of the peaks in biogenic $\mathrm{P}$ and fish debris fragments differ, however. This can be explained by variations in the size of the fish debris fragments and the fact that at the relatively low biogenic P concentrations observed here, fish debris may be more abundant in the size fraction $<150 \mu \mathrm{m}$ (Schenau and de Lange, 2000). For core $\mathrm{BC} 19$, an additional factor is the difference in total $\mathrm{P}$ contents in the sapropel of the two subcores used (Fig. 5). Apparently, fish debris deposits can vary in magnitude over short lateral distances.

\section{DISCUSSION}

\subsection{Original Sapropel S1 and the Oxidation Front}

Detailed studies of the sulfur geochemistry of sapropel S1 (Passier et al., 1996, 1997, 1999) indicate that sulfate reduction was the main respiratory pathway in the surface sediment during its formation. This resulted in fast formation of framboidal pyrite in the sapropel. Directly below the sapropel, in the formerly oxic sediment, Fe (hydr-)oxides acted as the main electron acceptor for organic matter decomposition. In this part of the sediment, slow formation of euhedral pyrite took place by sulfide diffusing downward from the sapropel. At the end of sapropel formation, the bottom water became oxygenated again, and active sulfate reduction in the sapropel came to a halt (Passier et al., 1996, 1997, 1999). Oxic sediment was deposited 


\section{SL35 (BC19-site)}

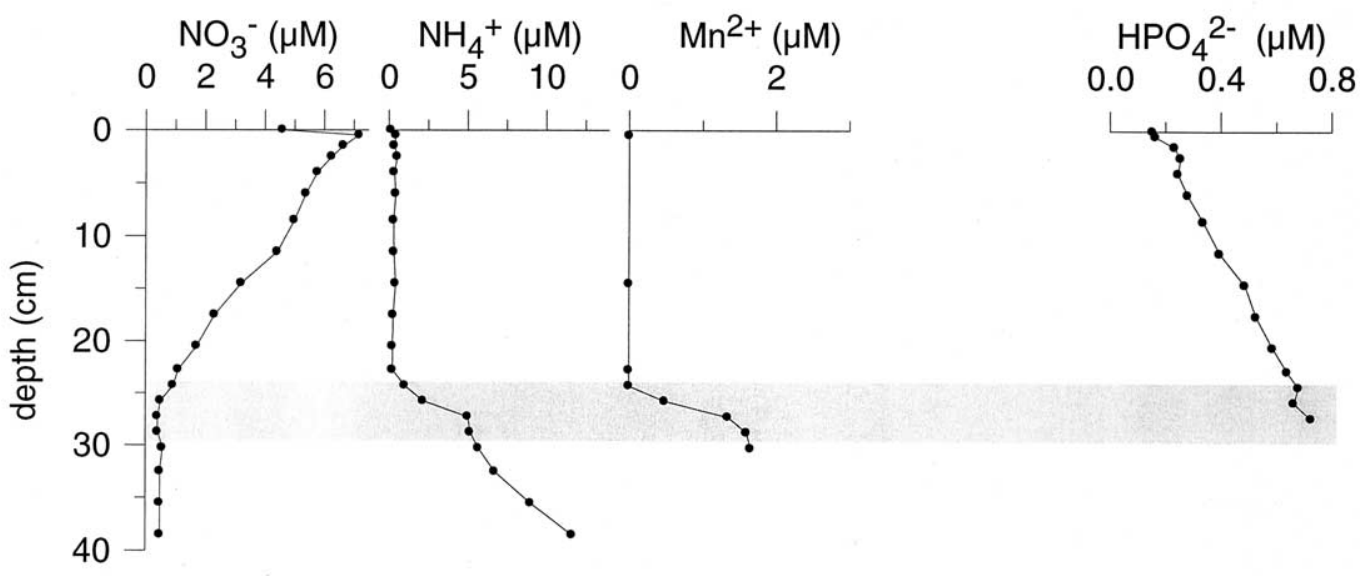

SL114

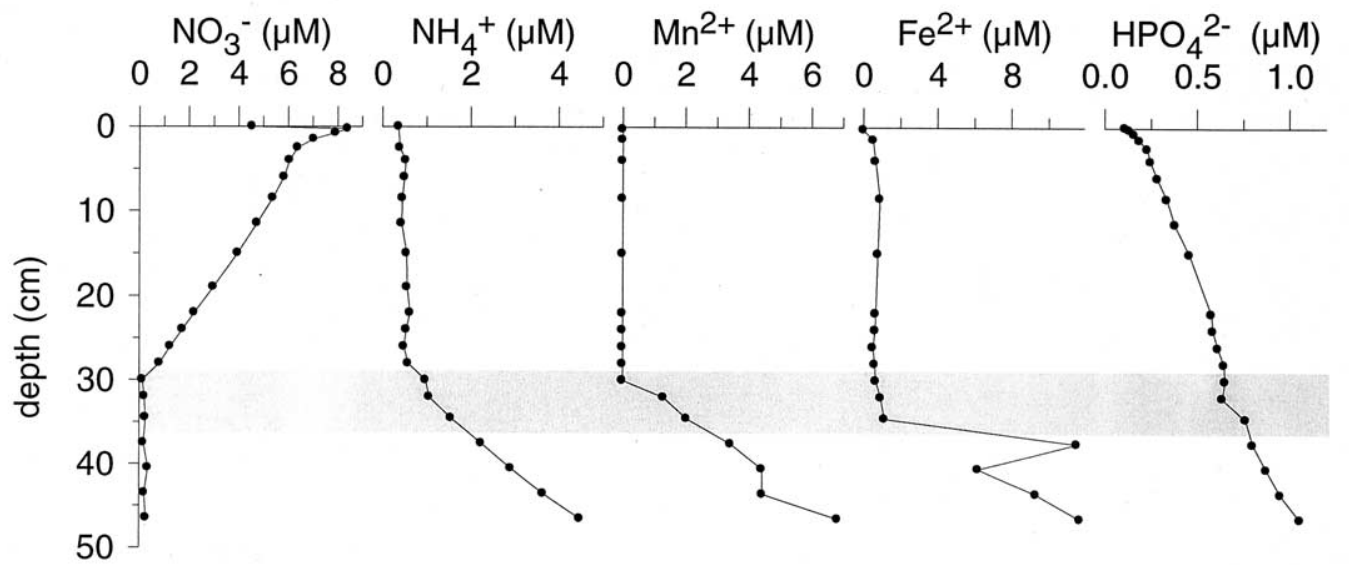

Fig. 3. Pore-water profiles of $\mathrm{NO}_{3}^{-}, \mathrm{NH}_{4}^{+}, \mathrm{Mn}^{2+}, \mathrm{Fe}^{2+}$, and $\mathrm{HPO}_{4}^{2-}$ for cores SL35 and SL114.

on top of the sapropel, and postdepositional oxidation of the upper part of the sapropel began (Van Santvoort et al., 1996).

At deep-basin sites with low sedimentation rates, the oxidation front is usually still progressing downward and thus is located at the top of the remaining organic-rich layer. Both the pore-water and solid-phase profiles of the two locations studied here (Figs. 2-4) are consistent with this oxidation front mechanism. At the front, $\mathrm{C}_{\text {org }}$ and pyrite and upward-diffusing dissolved $\mathrm{Fe}^{2+}$ and $\mathrm{Mn}^{2+}$ are oxidized by downward-diffusing $\mathrm{O}_{2}$ (Van Santvoort et al., 1996) and $\mathrm{NO}_{3}^{-}$. Consequently, $\mathrm{Fe}$ and $\mathrm{Mn}$ (hydr-)oxides are being formed. In addition, $\mathrm{NH}_{4}^{+}$ produced from organic matter decomposition below the sapropel, is oxidized to $\mathrm{NO}_{3}^{-}$. Elevated $\mathrm{Ba}$ concentrations in the sediment indicate the depth interval of the original sapropel. The $\mathrm{Ba}$ is in the form of biogenic barite and has been shown to be a proxy for the original organic $\mathrm{C}$ content in S1 (Van Santvoort et al., 1996). The top of the original sapropel also coincides with the upper hydrogenetic Mn peak (Thomson et al., 1995, 1999; Van Santvoort et al., 1996) and is indicated with a dashed line in Figure 2. A substantial fraction of the sapropel in cores BC19 and SL114 has been oxidized (49 and
$37 \%$ of the original thickness of the S1 interval, respectively; Fig. 2).

Sedimentation rates calculated from the positions of the sapropel and volcanic ash, and from radiocarbon dating (BC19) are listed in Table 1. Values obtained with the different calculations are similar and are in the range typical for eastern Mediterranean deep-basin sediments: 2 to $4 \mathrm{~cm} \mathrm{kyr}^{-1}$ (Van Santvoort et al., 1996; Mercone et al., 2000). Sedimentation rates during and after S1 formation were similar (BC19 in Table 1; Mercone et al., 2000). The greater extent of oxidation for BC19 compared with SL114 is in line with the lower sedimentation rate at the former site, resulting in a shorter diffusion pathway for $\mathrm{O}_{2}$ and $\mathrm{NO}_{3}^{-}$. The rate of downward movement of the oxidation front is low relative to the rate of diffusion of dissolved compounds. As a consequence, dissolved products of the oxidation of the sapropel (e.g., $\mathrm{SO}_{4}^{2-}$, dissolved inorganic carbon) will not show up in the pore-water profiles.

Detailed study of the $\mathrm{S}$ and Fe chemistry of sapropel S1 has shown that most of the diagenetic alteration of the visual, unoxidized sapropel took place during and shortly after its formation. Postburial sulfate reduction and pyrite formation 
BC19

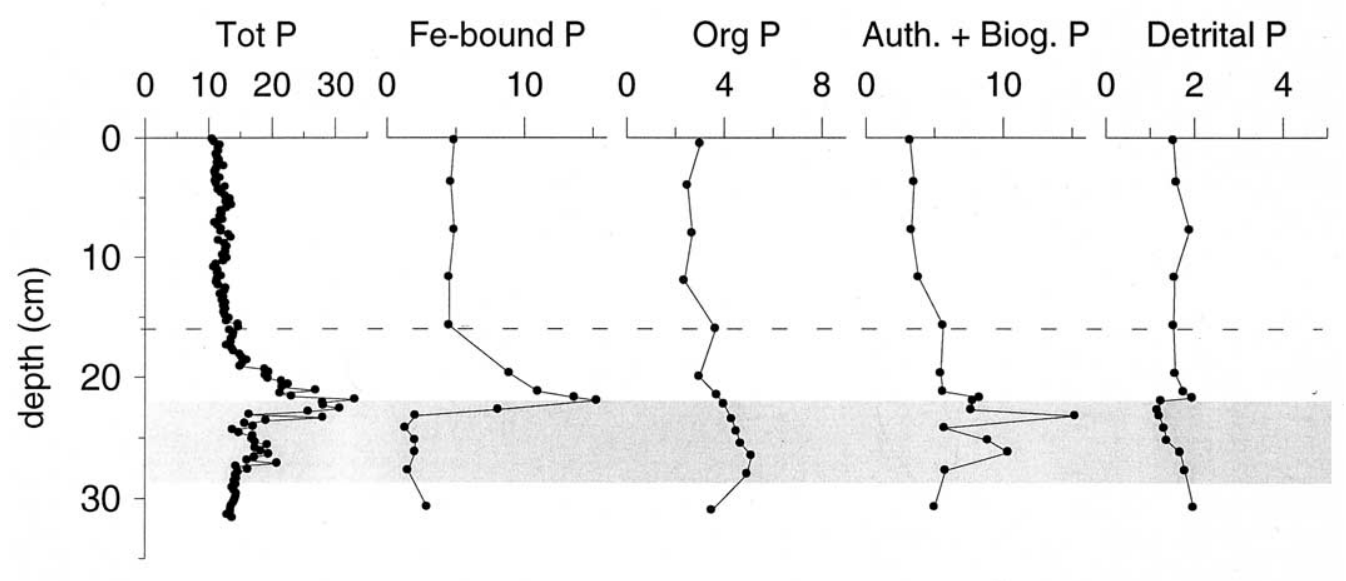

SL114

$P$ in $\mu \mathrm{mol} / \mathrm{g}$

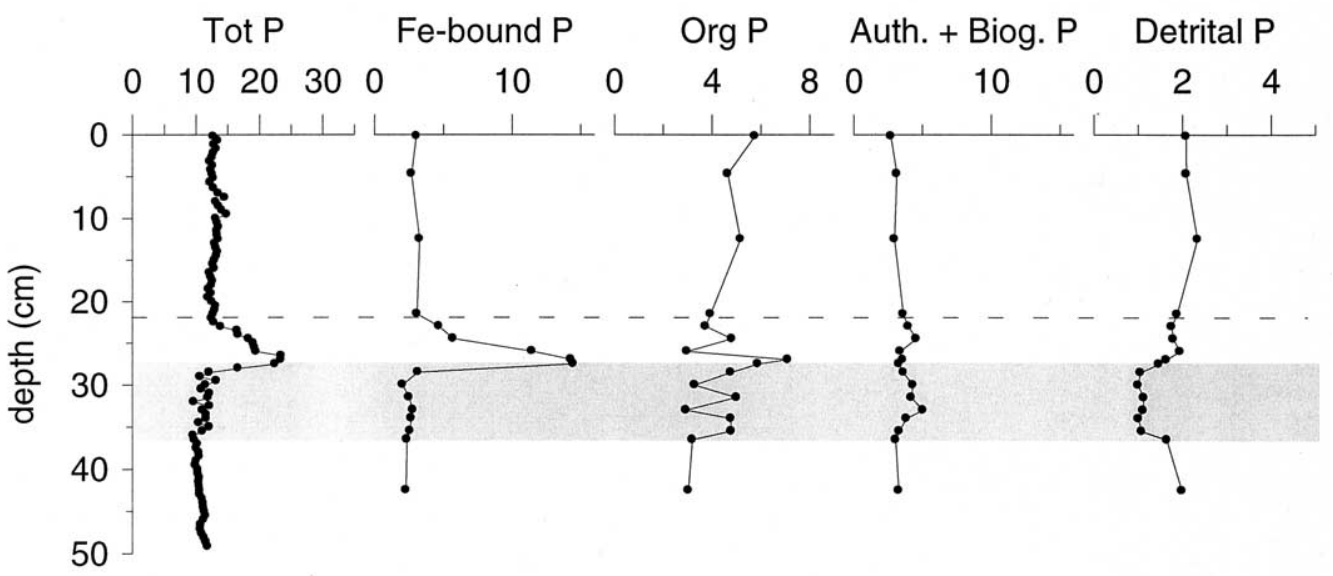

Fig. 4. Solid-phase profiles of total $\mathrm{P}$, Fe-bound $\mathrm{P}$, organic $\mathrm{P}$, authigenic + biogenic $\mathrm{P}$, and detrital $\mathrm{P}($ all in $\mu \mathrm{mol} / \mathrm{g}$ ) for cores BC19 and SL114.

have not been significant in this sapropel (Passier et al., 1997, 1999; Passier and de Lange, 1998). The absence of present-day sulfate reduction is reflected in the lack of a gradient in dissolved sulfate (Emeis et al., 1996) and the virtual absence of AVS and elemental $\mathrm{S}$ in this type of sediment (Passier et al., 1997, 1999; Passier and de Lange, 1998). Apparently, the reactivity of the organic matter in the visual sapropel is too low to sustain sulfate reduction (de Lange et al., 1994; Passier and de Lange, 1998). In the absence of active organic matter decomposition and postdepositional sulfidization, the chemical signals in the visual sapropel can be used to reconstruct the diagenesis of $\mathrm{P}$ during sapropel formation.

\subsection{Sedimentary P Cycle during Sapropel S1 Formation: Evidence for Enhanced Regeneration}

The low concentrations of Fe-bound $\mathrm{P}$ and Fe-oxides (Figs. 2 and 4) in and below the visual sapropel are in agreement with the work of Passier et al. (1999), who showed that during sapropel $\mathrm{S} 1$ formation all reactive $\mathrm{Fe}$ in and immediately below the sapropel was converted to pyrite. The presence of some Fe oxides in the visual sapropel in core BC19 (Fig. 2) is probably an artifact due to oxidation of pyrite during sample processing. Most $\mathrm{P}$ originally associated with the reactive Fe was released during sapropel formation.

In contrast to organic $\mathrm{C}$, organic $\mathrm{P}$ concentrations in the visual sapropel are not much higher than in nonsapropel layers. The organic matter in eastern Mediterranean sapropels is predominantly of marine origin (Emeis et al., 1996; Bosch et al., 1998). Therefore, the Redfield ratio (106) may be used as an approximation of the original $\mathrm{C} / \mathrm{P}$ ratio of the organic matter. Organic $\mathrm{C} / \mathrm{P}$ values in the sapropel are much higher and range from $\sim 300$ to 1085 (Fig. 6). These values are similar to organic $\mathrm{C} / \mathrm{P}$ ratios observed for modern anoxic Black Sea sediments (on average 558; Van Cappellen and Ingall, 1997) and Arabian Sea sediments in the oxygen minimum zone $(\sim 400$ to 800 ; Schenau and de Lange, 2001). They are lower than the average value of 3900 observed for Devonian laminated shales (Ingall et al., 1993). In the overlying and underlying sediments much lower values of organic C/P were found ( $\sim 18$ to 170$)$. The 


\section{BC19}

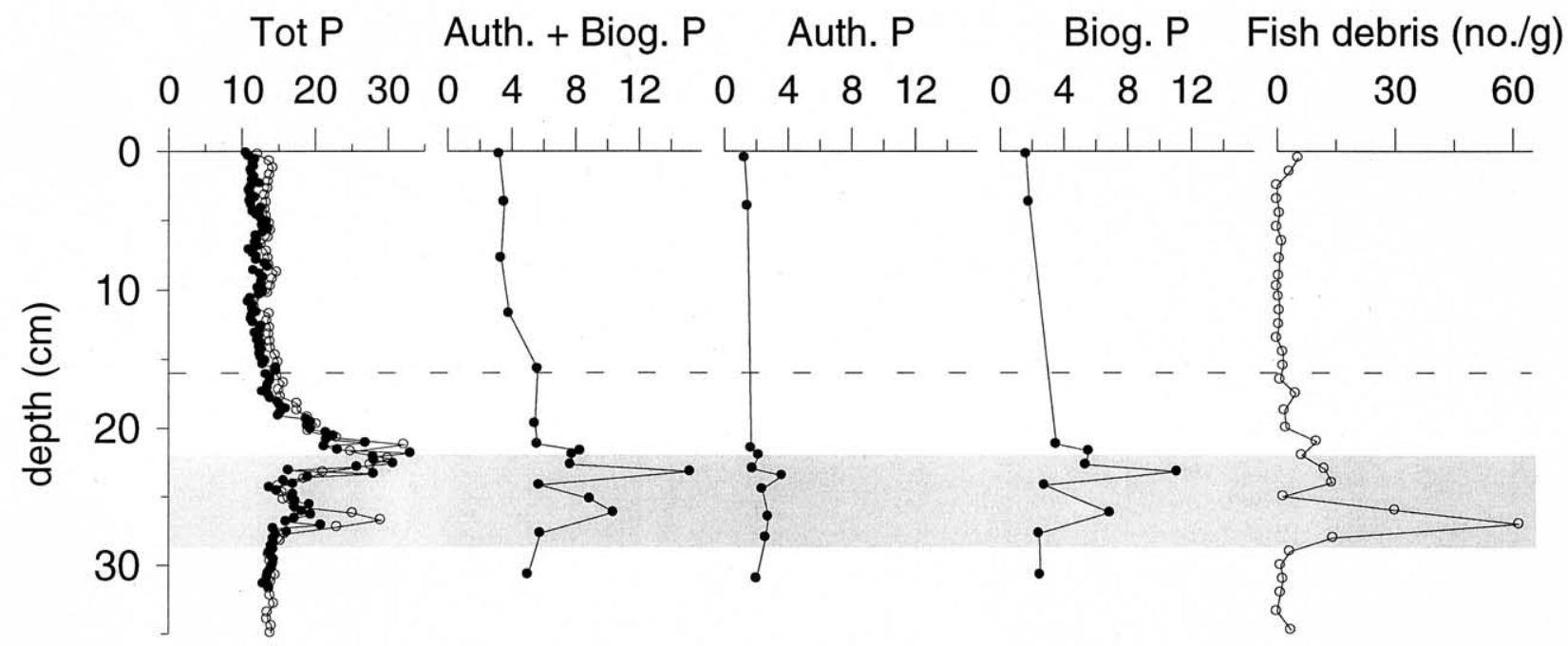

SL114

\section{$P$ in $\mu \mathrm{mol} / g$}

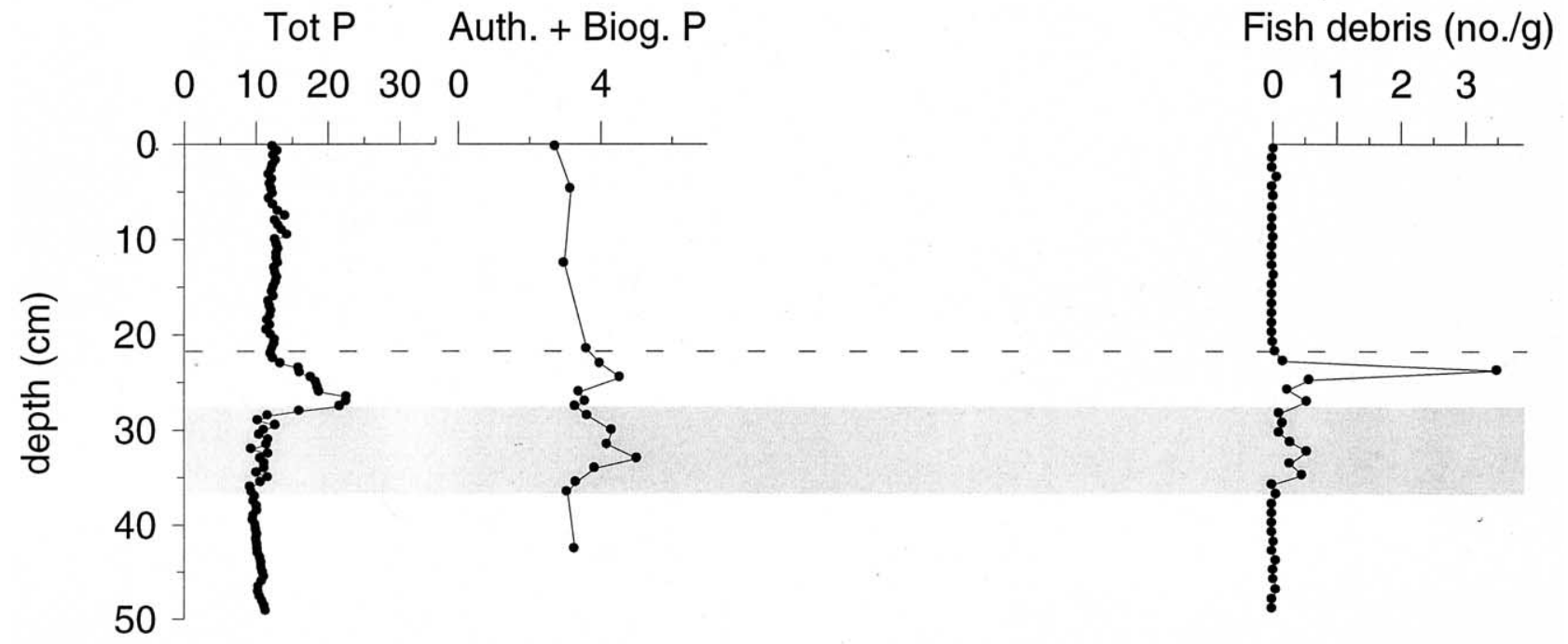

Fig. 5. Solid-phase profiles of total $\mathrm{P}$ (BC19; two subcores), authigenic + biogenic $\mathrm{P}$, authigenic $\mathrm{P}$, biogenic $\mathrm{P}$ (all in $\mu \mathrm{mol} / \mathrm{g}$ ), and fish debris (number/g) for cores BC19 and SL114. Note the difference in scale between the authigenic + biogenic $\mathrm{P}$ and fish debris contents for the two cores.

organic C/P ratios therefore support enhanced regeneration of organic $\mathrm{P}$ relative to organic $\mathrm{C}$ during sapropel $\mathrm{S} 1$ deposition.

The organic C/P ratios indicate that the enhanced regeneration occurred in the sapropel itself but not in the underlying nonsapropel sediment. Because sulfate reducers were only active in the sapropel (Passier et al., 1996, 1997, 1999), this suggests that these microorganisms may have played a key role in the preferential release of $\mathrm{P}$ relative to $\mathrm{C}$ from organic matter under anoxic conditions. Anaerobic microorganisms are not as efficient in accumulating and storing $\mathrm{P}$ as aerobic microorganisms and may lose part of their intracellular dissolved $\mathrm{P}$ through transport out of the cells (e.g., Gächter et al., 1988). Our results suggest that in the absence of an oxic surface layer, sulfate reduction leads to P-depleted residual organic matter in the sediment. This provides an alternative mechanism-unrelated to the Fe cycle-for the correlation between sulfate concentrations and $\mathrm{P}$ release from sediments demonstrated for a wide range of aquatic systems (Caraco et al., 1989), the enhanced $P$ release from lake sediments in response to sulfate additions (Curtis, 1989), and the observation that Arabian Sea sediments with the highest sulfate reduction rates have the lowest $\mathrm{P}$ contents (Lückge et al., 1999). The efficiency of aerobic organisms in retaining $\mathrm{P}$ is evident from the low organic $\mathrm{C} / \mathrm{P}$ ratios in the oxidized part of the sapropel. During burndown of the sapropel, the organic $\mathrm{C} / \mathrm{P}$ ratio decreased mainly because of respiration of organic $\mathrm{C}$. 
Table 1. Sedimentation rates. ${ }^{\text {a }}$

\begin{tabular}{lcc}
\hline Sedimentation rates $\left(\mathrm{cm} \mathrm{ky}^{-1}\right)$ based on: & BC19 & SL114 \\
\hline Start of S1 formation & 2.8 & 3.6 \\
End of S1 formation & 2.6 & 3.4 \\
Ash layer & 2.9 & - \\
Radiocarbon dating & 2.9 & - \\
\hline
\end{tabular}

a Sedimentation rates are calculated from $\left({ }^{1}\right)$ the positions of the original boundaries of sapropel S1, assuming the start and end of sapropel formation at 10.3 and $6.4 \mathrm{ky} \mathrm{BP}$ (corresponding to 9.5 and 6.0 ky BP in radiocarbon convention years, respectively; Mercone et al., $2000 ;\left({ }^{2}\right)$ the position of an ash layer at 10.5-cm depth (BC19: Minoan eruption of Santorini at $3.6 \mathrm{ky} \mathrm{BP}$ ); ( $\left.{ }^{3}\right)$ linear regression on radiocarbon dating of foraminiferal samples ( $G$. ruber) from four sediment depths between 10.5 and $30 \mathrm{~cm}$.

The reduced burial of Fe-bound $\mathrm{P}$ and organic $\mathrm{P}$ during sapropel formation is also evident when comparing the burial fluxes of organic $\mathrm{C}$, organic $\mathrm{P}, \mathrm{Fe}$-bound $\mathrm{P}$, and the ratio of organic $\mathrm{C}$ and organic $\mathrm{P}$ fluxes during and after sapropel $\mathrm{S} 1$ formation (Table 2). Whereas burial fluxes of organic $\mathrm{C}$ increased up to a factor of nine during sapropel formation, the burial flux of organic P and Fe-bound P decreased. This decreased burial of organic $\mathrm{P}$ and Fe-bound $\mathrm{P}$ may have been partly compensated by enhanced burial of reactive Ca-P (Van Cappellen and Ingall, 1994). This should be reflected in an increase in the burial flux of authigenic + biogenic P during S1 relative to the flux after $\mathrm{S} 1$. This is observed for site BC19 (Table 2). The enhanced burial only partly compensates the enhanced release of $\mathrm{P}$ during $\mathrm{S} 1$ formation, however. This is evident from the decreased $\mathrm{P}_{\text {total }}$ fluxes during sapropel formation and the $\mathrm{C}_{\text {org }} /\left(\mathrm{P}_{\text {org }}+\mathrm{P}_{\text {auth }}+\right.$ bio $)$ and $\mathrm{C}_{\text {org }} / \mathrm{P}_{\text {total }}$ flux ratios (Table 2), which remain significantly higher than the Redfield ratio and than values after $\mathrm{S} 1$. In conclusion, enhanced burial of reactive Ca-P may have occurred at some sites during $\mathrm{S} 1$ formation, but this only partly compensated the enhanced release from organic matter and Fe-oxides.

The reactive $\mathrm{Ca}-\mathrm{P}$ in the sapropel is largely in the form of biogenic Ca-P (i.e., phosphatic fish debris). The presence of fish debris in the sapropel can be explained by either increased preservation or increased production. We expect both are important. Increased primary productivity will lead to more abun-

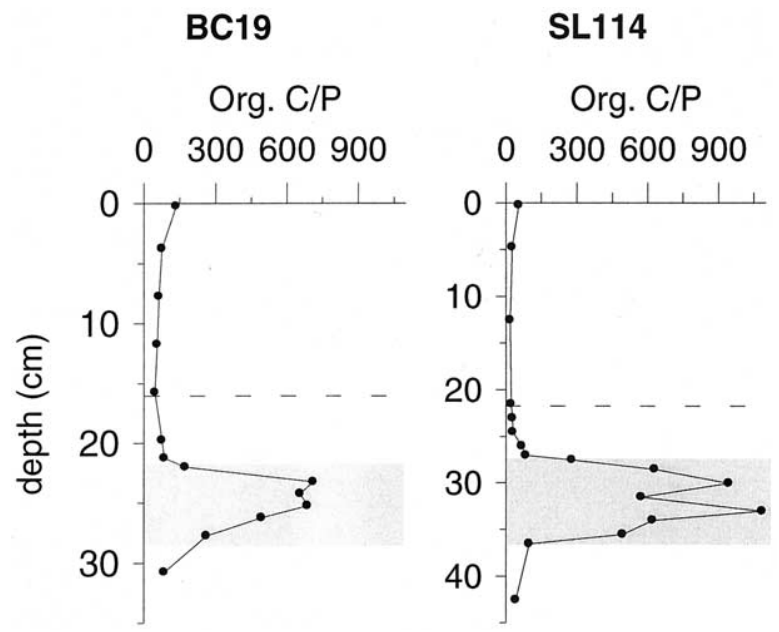

Fig. 6. Profiles of organic $\mathrm{C} / \mathrm{P}(\mathrm{mol} / \mathrm{mol})$ for cores $\mathrm{BC} 19$ and SL114.

dant fish populations in the oxic part of the water column and higher rates of fish debris deposition (Suess, 1981; DeVries and Pearcy, 1982; Tunnicliffe et al., 2001). Changes in the extent of the anoxic part of the water column could lead to a periodic decrease in the number of living fish, perhaps through local fish kills, as have been reported for the Arabian Sea (Banse, 1968). This could temporarily increase deposition rates and lead to high spatial variability in fish debris deposits. Evidence from both archeological (Collins et al., 1999) and marine geochemical research (Schenau and de Lange, 2000) suggest better preservation of bone material under anoxic than under oxic conditions. Better preservation would also explain the layers of almost intact fish skeletons that have been observed in a sapropel of the Pleistocene Vrica section (Calabria Italy, cycle i-178; L. J. Lourens, personal communication). The fact that there is still some fish debris present in the oxidized part of the sapropel in both cores suggests that factors related to the anoxia-and not the anoxia itself—are most likely the cause of the preservation.

Reconstruction of the sedimentary $\mathrm{P}$ cycle during sapropel times requires an estimate of the average rates of deposition and burial of reactive $P$. The sediment-water exchange of

Table 2. Average burial fluxes of organic $\mathrm{C}$, organic $\mathrm{P}$, Fe-bound $\mathrm{P}$, authigenic + biogenic $\mathrm{P}$, total $\mathrm{P}$, and the ratios of the burial fluxes of organic $\mathrm{C}$ and several P forms for cores BC19 and SL114 during and after sapropel S1 formation. ${ }^{\mathrm{a}}$

\begin{tabular}{|c|c|c|c|c|}
\hline \multirow[b]{2}{*}{ Burial flux } & \multicolumn{2}{|c|}{ BC19 } & \multicolumn{2}{|c|}{ SL114 } \\
\hline & During S1 & After S1 & During S1 & After S1 \\
\hline $\mathrm{C}_{\mathrm{org}}\left(\mathrm{mmol} \mathrm{m}^{-2} \mathrm{yr}^{-1}\right)$ & 40 & 6.0 & 40 & 4.4 \\
\hline $\mathrm{P}_{\mathrm{org}}\left(\mu \mathrm{mol} \mathrm{m} \mathrm{m}^{-2} \mathrm{yr}^{-1}\right)$ & $62(24 \%)$ & $70(23 \%)$ & $58(29 \%)$ & $128(38 \%)$ \\
\hline $\mathrm{P}_{\mathrm{Fe}}\left(\mu \mathrm{mol} \mathrm{m}{ }^{-2} \mathrm{yr}^{-1}\right)$ & $24(9 \%)$ & $126(41 \%)$ & $36(18 \%)$ & $82(24 \%)$ \\
\hline $\mathrm{P}\left(\mu \mathrm{mol} \mathrm{m}^{-2} \mathrm{yr}^{-1}\right)$ & $119(46 \%)$ & $94(31 \%)$ & $62(31 \%)$ & $81(24 \%)$ \\
\hline $\mathrm{P}_{\text {total }}\left(\mu \mathrm{mol} \mathrm{m}^{-2} \mathrm{yr}^{-1}\right)$ & 257 & 307 & 202 & 342 \\
\hline $\mathrm{C}_{\text {org }} / \mathrm{P}_{\text {org }}$ & 652 & 86 & 686 & 34 \\
\hline $\mathrm{C}_{\mathrm{org}} /\left(\mathrm{P}_{\mathrm{org}+} \mathrm{P}_{\text {auth }+ \text { bio }}\right)$ & 223 & 37 & 331 & 21 \\
\hline $\mathrm{C}_{\text {org }} / \mathrm{P}_{\text {total }}$ & 156 & 20 & 198 & 13 \\
\hline
\end{tabular}

${ }^{a}$ Percentages in parentheses are percentages of the total $\mathrm{P}$ flux. The fluxes were calculated from the integrated amounts of each component in the sapropel (flux during S1) and from concentrations in the upper $\sim 12 \mathrm{~cm}$ of the sediment (flux after S1) using the dry bulk densities and the sedimentation rate for each location (Table 1; for BC19, based on radiocarbon; for SL114, based on average value). 
Table 3. Burial efficiencies and burial and depositional fluxes of organic $\mathrm{C}$, organic $\mathrm{P}$, and reactive $\mathrm{P}$, rates of organic $\mathrm{C}$ decomposition, and sediment-water exchange rates of $\mathrm{HPO}_{4}^{2-}$ for cores BC19 and SL114 during sapropel S1 deposition. ${ }^{\mathrm{a}}$

\begin{tabular}{|c|c|c|c|c|c|}
\hline \multirow[b]{2}{*}{ Parameter } & \multicolumn{2}{|c|}{ BC19 } & \multicolumn{3}{|c|}{ SL114 } \\
\hline & Sox $0 \%$ & Sox $80 \%$ & Sox $0 \%$ & & Sox $80 \%$ \\
\hline $\mathrm{BE}$ for organic $\mathrm{C}$ & $54 \%$ & \multirow[t]{2}{*}{$19 \%$} & $54 \%$ & \multirow{4}{*}{0.48} & $19 \%$ \\
\hline Burial flux organic $\mathrm{C}\left(\mathrm{g} \mathrm{m}^{-2} \mathrm{yr}^{-1}\right)$ & & & & & \\
\hline Depositional flux organic $\mathrm{C}\left(\mathrm{g} \mathrm{m}^{-2} \mathrm{yr}^{-1}\right)$ & 0.90 & 2.56 & 0.88 & & 2.50 \\
\hline $\mathrm{BE}$ for organic $\mathrm{P}$ & $9 \%$ & $3 \%$ & $8 \%$ & & $3 \%$ \\
\hline \multicolumn{6}{|l|}{ Depositional flux $\left(\mu \mathrm{mol} \mathrm{m} \mathrm{m}^{-2} \mathrm{yr}^{-1}\right)$ of: } \\
\hline Organic $\mathrm{P}$ & 706 & 2012 & 694 & & 1965 \\
\hline Fe-bound $\mathrm{P}^{\mathrm{b}}$ & \multirow{2}{*}{\multicolumn{2}{|c|}{$\begin{array}{c}75 \\
878\end{array}$}} & \multirow{2}{*}{\multicolumn{3}{|c|}{$\begin{array}{c}62 \\
312\end{array}$}} \\
\hline Biogenic P & & & & & \\
\hline Depositional flux reactive $\mathrm{P}^{\mathrm{c}}\left(\mu \mathrm{mol} \mathrm{m}{ }^{-2} \mathrm{yr}^{-1}\right)$ & 1660 & 2965 & 1068 & \multirow{3}{*}{156} & 2339 \\
\hline Burial flux reactive $\mathrm{P}\left(\mu \mathrm{mol} \mathrm{m} \mathrm{m}^{-2} \mathrm{yr}^{-1}\right)$ & & & & & \\
\hline $\begin{array}{l}\text { Sediment-water exchange flux of } \mathrm{HPO}_{4}^{2-} \\
\left(\mu \mathrm{mol} \mathrm{m}{ }^{-2} \mathrm{yr}^{-1}\right)\end{array}$ & 1455 & 2760 & 912 & & 2183 \\
\hline $\mathrm{BE}$ for reactive $\mathrm{P}$ & 12 & 7 & 15 & & 7 \\
\hline
\end{tabular}

${ }^{\text {a }}$ Sox $0 \%$-no sulfide reoxidation, Sox $80 \%-80 \%$ of the sulfide formed is reoxidized.

${ }^{\mathrm{b}}$ Including release of Fe-bound $\mathrm{P}$ as a result of downward sulfidization of the sediment below the sapropel amounting to $16 \%$ and $34 \%$ of the flux of Fe-bound P for cores BC19 and SL114, respectively. Because the lower boundary of the S-enriched zone was not recovered in core BC19, the release of Fe-bound $\mathrm{P}$ due to downward sulfidization may be slightly underestimated for this core.

${ }^{\mathrm{c}}$ Reactive $\mathrm{P}$ is defined as the sum of organic, Fe-bound, and biogenic P.

$\mathrm{HPO}_{4}^{2-}$ can then be calculated as the difference between the depositional and burial flux of reactive $P$. There are three potential sources of reactive $\mathrm{P}$ to the sediment: organic $\mathrm{P}$, Fe-bound $\mathrm{P}$, and biogenic Ca-P.

The depositional flux of organic $\mathrm{P}$ can be estimated from the average burial flux of organic $\mathrm{C}$ (Table 2), the burial efficiency of organic $\mathrm{C}$ in the sapropel (defined as the percentage of the deposited $\mathrm{C}_{\text {org }}$ that is buried), and the organic $\mathrm{C} / \mathrm{P}$ ratio of the deposited organic matter. Here, we assume a Redfield organic $\mathrm{C} / \mathrm{P}$ ratio of 106 . Because some loss of $\mathrm{P}$ relative to $\mathrm{C}$ will probably have occurred during downward transport through the water column, the organic $\mathrm{P}$ deposition flux estimates are maximum values. Because all organic matter remineralization in the sediment took place by sulfate reduction, the burial efficiency of organic $C$ (expressed as percentages) can be calculated as (Passier et al., 1999) follows:

$$
\mathrm{BE}=\frac{\mathrm{C}_{\mathrm{int}}}{2 \times \mathrm{f} \times \mathrm{S}_{\mathrm{int}}+\mathrm{C}_{\mathrm{int}}} \times 100 \%,
$$

where

$$
f=\frac{100}{100-b}
$$

and where $\mathrm{b}$ is the percentage of total produced sulfide that was reoxidized, and $\mathrm{C}_{\text {int }}$ and $\mathrm{S}_{\text {int }}$ (both in $\mathrm{mol} \mathrm{m} \mathrm{m}^{-2}$ ) are the depth integrated amounts of organic $\mathrm{C}$ and reduced $\mathrm{S}$ in and below the sapropel, respectively.

When assuming no sulfide reoxidation, the burial efficiency of organic $\mathrm{C}$ is $54 \%$ for both sites. When assuming a reoxidation of $80 \%$ (Passier et al., 1999), the calculated burial efficiency of organic C is $19 \%$ (Table 3). This value is close to the value of $16 \%$ calculated for sapropel S1 by Passier et al. (1999) and falls within the lower part of the range of 13 to $48 \%$ reported by Canfield (1989) for low sedimentation sites in euxinic environments.

Burial fluxes of organic $\mathrm{C}$ during sapropel $\mathrm{S} 1$ times are $\sim 0.5$ $\mathrm{g} \mathrm{C} \mathrm{m}^{-2} \mathrm{yr}^{-1}$. This amounts to $\sim 1.8 \%$ of present-day primary production in the eastern Mediterranean $\left(26 \mathrm{~g} \mathrm{C} \mathrm{m}^{-2} \mathrm{yr}^{-1}\right.$; Béthoux, 1989) and to $\sim 0.4 \%$ of the primary production estimated for $\mathrm{S} 1$ from Ba contents $\left(118 \mathrm{~g} \mathrm{C} \mathrm{m}^{-2} \mathrm{yr}^{-1}\right.$; Passier et al., 1999). These percentages are much lower than the maximum preservation factor (defined as the primary production that is buried) of 5\% observed for the present euxinic Black Sea (Arthur et al., 1994), but are higher than the $0.2 \%$ calculated for oxic sediments in the present-day Mediterranean (Howell and Thunell, 1992). The fact that preservation efficiencies of organic $\mathrm{C}$ are intermediate between values for the euxinic Black Sea and the present-day Mediterranean could be explained by dysoxic or semieuxinic rather than euxinic conditions in the water column during S1 formation. This is consistent with water column conditions derived for S1 times from pyrite properties (Passier et al., 1999) and from benthic foraminiferal and trace metal data (Mercone et al., 2001). Burial efficiencies of organic P range from 3 to $9 \%$ (Table 3) and are thus much lower than those for organic $\mathrm{C}$.

Because of the low oxygen concentrations in most of the water column during sapropel formation, a major part of the $\mathrm{P}$ bound to Fe-oxides will have been released to the dissolved phase before reaching the sediment. As a consequence, the depositional flux of Fe-bound $\mathrm{P}$ will have been small. As a maximum estimate, we will assume here that this flux of Fe-bound P amounts to $50 \%$ of the burial flux of Fe-bound $\mathrm{P}$ after S1 formation (Table 2). Because of downward sulfidization (Passier et al., 1996), Fe-bound P will have been released below the sapropel. This will have been a small additional source of dissolved P. Assuming that the Fe-P concentration below the sapropel was originally similar to that of the oxic surface sediment, the average $\mathrm{P}$ release due to sulfidization can be calculated from the integrated amount of "missing" $P$ in the sulfidized zone and the duration of S1.

The depositional flux of biogenic $\mathrm{P}$ can be calculated from the burial flux of biogenic $\mathrm{P}$ and its burial efficiency, which is 
Table 4. Sediment-water exchange rates of $\mathrm{HPO}_{4}^{2-}$ for different types of marine environments. The terms "anoxic" and "oxic" refer to the bottom water oxygen concentrations $(<10 \mu \mathrm{M}$ and $>10 \mu \mathrm{M}$, respectively).

\begin{tabular}{lccr}
\hline & \multicolumn{2}{c}{ Range $\left(\mu \mathrm{mol} \mathrm{m}^{-2} \mathrm{yr}^{-1}\right)$} & \\
\cline { 2 - 3 } \multicolumn{1}{c}{ Site } & Anoxic & Oxic & Source $^{\mathrm{a}}$ \\
\hline Deep sea & & & \\
$\quad$ East Mediterranean & $\sim 910-2760$ & $\sim 70-120$ & $(1)$ \\
$\quad \begin{array}{l}\text { South Atlantic Ocean } \\
\text { (central part) }\end{array}$ & - & $\sim-2000-1000$ & $(2)$ \\
$\quad$ Arabian Sea & - & $\sim-1000-500$ & \\
Continental margin & & & \\
$\quad$ Arabian Sea & $\sim 2900-6440$ & $\sim 300-1300$ \\
$\quad$ California margin & $\sim 5500-59000$ & $\sim 0-29600$ \\
$\quad$ North Sea & - & $\sim-12000-620000$ & $(3)$ \\
\hline
\end{tabular}

a Sources: (1) This study (anoxic: S1 times; oxic, present day); (2) Hensen et al. (1998); (3) Schenau and de Lange (2001); (4) Ingall and Jahnke (1997); (5) Slomp et al. (1998).

defined as the percentage of the deposited biogenic $\mathrm{P}$ that is buried. Seawater is undersaturated with respect to biogenic Ca-P (Atlas and Pytkowicz, 1977). As a consequence, a major proportion of the fish debris reaching the sediment is expected to dissolve in the top few centimeters of the sediment (DeVries and Pearcy, 1982; Froelich et al., 1982; Van Cappellen and Berner, 1988). Assuming that little dissolution occurs in the water column because of rapid sinking rates (Schenau and de Lange, 2000), burial efficiencies will be close to preservation potentials defined as the fraction of fish produced in the surface water that is buried in the sediment. Preservation potentials have been estimated to range between $\sim 2.5$ and $22.5 \%$ for Arabian Sea sediments (Schenau and de Lange, 2000) and to be equal to $\sim 10 \%$ for sediments in the upwelling area offshore Peru (Suess, 1981; Froelich et al., 1982). For sapropel times, we will assume a burial efficiency of $\sim 10 \%$. Burial fluxes of biogenic $\mathrm{P}$ were obtained by subtracting the background flux of $\mathrm{P}_{\text {auth }}$ of $31 \mu \mathrm{mol} \mathrm{P} \mathrm{m}{ }^{-2} \mathrm{yr}^{-1}$ calculated for BC19 (Fig. 5) from the $\mathrm{P}_{\text {auth }}+$ bio-fluxes for both locations (Table 2).

Burial fluxes of total $\mathrm{P}$ during sapropel formation (Table 2) are within the range typical for open ocean regions (20 to 750 $\mu \mathrm{mol} \mathrm{m} \mathrm{yr}^{-1}$; Filipelli, 1997). The burial efficiency of reactive $\mathrm{P}$ in sapropels is low, ranging between 7 and $15 \%$ (Table 3). These values are close to the values of 6 and $12 \%$ observed by Ingall and Jahnke (1994) for the anoxic Peru Margin and Santa Monica Basin, respectively. Sediment-water exchange rates of $\mathrm{HPO}_{4}^{2-}$ - calculated as the difference between the average depositional and burial flux of reactive $\mathrm{P}$ to the sediment—range from $\sim 910$ to $2760 \mu \mathrm{mol} \mathrm{m}^{-2} \mathrm{yr}^{-1}$, with the highest values corresponding to the lowest burial efficiency for $\mathrm{C}_{\text {org }}$. These rates calculated for $\mathrm{S} 1$ times are significantly higher than present-day sediment-water exchange rates at these sites, or most values typical for present-day oxic deep-sea environments (Table 4; Colman and Holland, 2000). When compared with modern oxic and anoxic continental margin environments, however, these rates are relatively low. Paleogradients of $\mathrm{HPO}_{4}^{2-}$ in the surface sediment necessary to maintain the $\mathrm{HPO}_{4}^{2-}$ flux during sapropel times are also low (0.7 to $2.0 \mu \mathrm{M}$ over a $1-\mathrm{cm}$ interval). This indicates that pore-water concentrations of $\mathrm{HPO}_{4}^{2-}$ in the surface sediment were only

\section{A: The sedimentary $\mathrm{P}$ cycle during $\mathrm{S} 1$ formation}

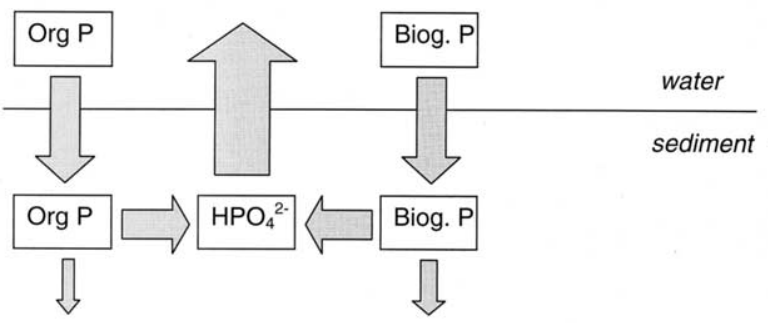

B: The present-day sedimentary P cycle

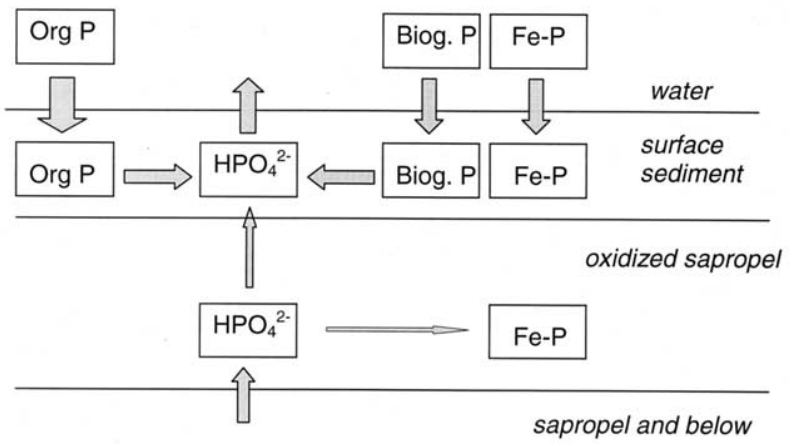

Fig. 7. Schematic representation of the sedimentary $\mathrm{P}$ cycle in the eastern Mediterranean Sea (A) during sapropel formation and (B) at present. Only reactive $\mathrm{P}$ forms are included.

slightly higher than the bottom-water concentration, which at the start of sapropel formation will have been close to the present-day value of $\sim 0.2 \mu \mathrm{M}$. These relatively low pore-water concentrations of $\mathrm{HPO}_{4}^{2-}$, may explain why authigenic carbonate fluorapatite (CFA) formation did not occur in the deepbasin during sapropel S1 times (Fig. 5).

The sedimentary $\mathrm{P}$ cycle during sapropel $\mathrm{S} 1$ formation is summarized in Figure 7A. All the $\mathrm{HPO}_{4}^{2-}$ released in the sediment returns to the water column. Organic $\mathrm{P}$ and biogenic $\mathrm{Ca}-\mathrm{P}$ formed in the water column are the major sources and sinks of reactive $\mathrm{P}$. The relative importance of biogenic Ca-P burial may vary in magnitude from site to site. Burial efficiencies are $<15 \%$ and most of the deposited $\mathrm{P}$ is returned to the water column. If we view sapropels as a modern analog of black shales (e.g., Nijenhuis et al., 1999; Thomson et al., 1999), the lack of CFA formation and the presence of abundant biogenic $\mathrm{Ca}-\mathrm{P}$ also has wider implications.

In their model calculations for global ocean $\mathrm{C}, \mathrm{P}$, and $\mathrm{O}$ cycling, Van Cappellen and Ingall $(1994,1996)$ assumed that CFA formation and burial increased during ocean anoxia as a result of increased primary production. This partly compensated the decreased burial of organic and Fe-bound P. If our results for Mediterranean sapropels are extrapolated to times of worldwide anoxia, then CFA formation may have been absent across most of the deep sea. Instead, enhanced burial of biogenic Ca-P may have been important. More insight into the factors determining the burial flux of biogenic $\mathrm{P}$ is needed to 
Table 5. Diffusive fluxes of $\mathrm{HPO}_{4}^{2-}$ and $\mathrm{Fe}^{2+}$, peak areas of $\mathrm{Fe}-$ bound $\mathrm{P}$ and $\mathrm{Fe}$ oxide, the time needed to build up these peaks at the present-day flux, the burial and depositional (calculated as the sum of the burial and sediment-water exchange flux) reactive $\mathrm{P}$ flux in the surface sediment, and the burial efficiency for reactive $\mathrm{P}$ in cores BC19 and SL114. ${ }^{\mathrm{a}}$

\begin{tabular}{|c|c|c|}
\hline Parameter & BC19 & SL114 \\
\hline \multicolumn{3}{|l|}{ Diffusive fluxes $\left(\mu \mathrm{mol} \mathrm{m}{ }^{-2} \mathrm{yr}^{-1}\right)$} \\
\hline Sediment-water exchange of $\mathrm{HPO}_{4}^{2-}$ & 68 & 123 \\
\hline $\begin{array}{l}\text { Intermediate flux of } \mathrm{HPO}_{4}^{2-} \text { from the top } \\
\text { of } \mathrm{S} 1 \text { to the sediment surface }\end{array}$ & 26 & 21 \\
\hline Deep flux of $\mathrm{HPO}_{4}^{2-}$ from below $\mathrm{S} 1$ & NA & 31 \\
\hline Deep flux of $\mathrm{Fe}^{2+}$ from below $\mathrm{S} 1$ & NA & 936 \\
\hline \multicolumn{3}{|l|}{ Peak areas $\left(\mu \mathrm{mol} \mathrm{m}{ }^{-2}\right)$} \\
\hline Fe-bound $\mathrm{P}$ & $3.2 \times 10^{5}$ & $2.5 \times 10^{5}$ \\
\hline Fe oxide & $7.2 \times 10^{6}$ & $8.5 \times 10^{6}$ \\
\hline \multicolumn{3}{|l|}{ Time needed at present-day flux (yr) } \\
\hline Fe-bound $\mathrm{P}$ & NA & $2.5 \times 10^{4}$ \\
\hline Fe oxide & NA & $9.1 \times 10^{3}$ \\
\hline Burial flux reactive $\mathrm{P}\left(\mu \mathrm{mol} \mathrm{m} \mathrm{m}^{-2} \mathrm{yr}^{-1}\right)$ & 224 & 214 \\
\hline $\begin{array}{l}\text { Depositional flux reactive } \\
\mathrm{P}\left(\mu \mathrm{mol} \mathrm{m}^{-2} \mathrm{yr}^{-1}\right)\end{array}$ & 293 & 336 \\
\hline $\mathrm{BE} P$ reactive & $77 \%$ & $64 \%$ \\
\hline
\end{tabular}

${ }^{a}$ Whole sediment diffusion coefficients for $13^{\circ} \mathrm{C}$ were calculated from measured porosities using the procedure of Krom and Berner (1980). NA $=$ not available.

assess the implications of this finding for the response of global $\mathrm{P}$ cycling to changes in productivity and ocean anoxia.

\subsection{Present-Day Sedimentary P Cycle}

The present-day cycle of $\mathrm{P}$ in these sediments can be deduced from the pore-water and solid-phase profiles. Two zones of major activity can be distinguished: the surface sediment, and the oxidation front.

In the surface sediment at both sites, the decrease in $\mathrm{C}_{\text {org }}$ (Fig. 2), the maxima in pore-water $\mathrm{NO}_{3}^{-}$and the steep gradients in $\mathrm{HPO}_{4}^{2-}$ (Fig. 3) indicate rapid degradation of $\mathrm{C}_{\text {org }}$, release of $\mathrm{NH}_{4}^{+}$and $\mathrm{HPO}_{4}^{2-}$ from organic matter and oxidation of the $\mathrm{NH}_{4}^{+}$to $\mathrm{NO}_{3}^{-}$. The activity at the surface is also evident from a rapid decrease in oxygen concentrations at site SL114 (R. R. Haese, personal communication). Below this bioturbated surface zone $\left(\sim 2 \mathrm{~cm}\right.$ based on ${ }^{210} \mathrm{~Pb}$ profiles; data not shown), near-linear diffusion curves of $\mathrm{NO}_{3}^{-}$and $\mathrm{HPO}_{4}^{2-}$ indicate little degradation of $\mathrm{C}_{\text {org }}$. Results of flux calculations (Table 5) are in line with this scenario. Diffusive fluxes of $\mathrm{HPO}_{4}^{2-}$ between the top of the sapropel and the surface sediment are too low to support the sediment-water exchange under steady-state conditions, indicating a near-surface source of $\mathrm{P}$ - that is, organic matter and perhaps biogenic $\mathrm{P}$.

At the oxidation front, $\mathrm{C}_{\text {org }}$ and pyrite and upward-diffusing dissolved $\mathrm{Fe}^{2+}$ and $\mathrm{Mn}^{2+}$ are oxidized by downward-diffusing $\mathrm{O}_{2}$ and $\mathrm{NO}_{3}^{-}$. Consequently, $\mathrm{Fe}$ and $\mathrm{Mn}$ (hydr-)oxides are being formed. Fe-bound $\mathrm{P}$ and pore-water $\mathrm{HPO}_{4}^{2-}$ profiles indicate that upward-diffusing $\mathrm{HPO}_{4}^{2-}$ from below the sapropel is sorbed to the Fe oxides. At station SL114, the present-day rate of $\mathrm{Fe}$-bound $\mathrm{P}$ formation, calculated as the difference between the deep and intermediate diffusive $\mathrm{HPO}_{4}^{2-}$ flux (Table 5; Fig. 3), amounts to $\sim 10 \mu \mathrm{mol} \mathrm{m}{ }^{-2} \mathrm{yr}^{-1}$. With this flux, it would take $\sim 25,000 \mathrm{yr}$ to build up the peak of Fe-bound $\mathrm{P}$ at this station. At the present-day diffusive flux of $\mathrm{Fe}^{2+}$, it would take $\sim 9000 \mathrm{yr}$ to build up the Fe-oxide peak. Taking into account that some $\mathrm{Fe}$ oxides were formed from oxidation of $\mathrm{Fe}$ sulfides in the sapropel, this suggests that average pore-water fluxes of $\mathrm{Fe}^{2+}$ because sapropel formation were not very different from those of today. This clearly does not hold for $\mathrm{HPO}_{4}^{2-}$. Apparently, the release of $\mathrm{HPO}_{4}^{2-}$ in deeper layers below the sapropel was initially much higher directly after sapropel times and is decoupled from that of $\mathrm{Fe}^{2+}$. This could be explained by release of $\mathrm{Fe}$-bound $\mathrm{P}$ before the actual reduction of the Fe-oxides (e.g., Lucotte et al., 1994), which occur as peaks above older sapropels (Passier et al., 1999).

The present-day sedimentary $\mathrm{P}$ cycle in sapropel-containing eastern Mediterranean sediments from the deep-basin is summarized in Figure 7B. Reactive $\mathrm{P}$ reaches the sediment as organic, biogenic, and Fe-bound $\mathrm{P}$. $\mathrm{HPO}_{4}^{2-}$ released from organic matter and biogenic $\mathrm{P}$ in the surface sediment is returned completely to the water column. Part of the $\mathrm{HPO}_{4}^{2-}$ diffusing upward from below the sapropel is bound to $\mathrm{Fe}$ oxides above the sapropel. The remaining $\mathrm{HPO}_{4}^{2-}$ escapes to the overlying water. Burial efficiencies for reactive $\mathrm{P}$ in the surface sediment, calculated as the ratio of the sediment-water exchange flux and the sum of the sediment-water exchange and burial flux of $\mathrm{P}$ (Table 5), are 64 and $77 \%$ for stations BC19 and SL114, respectively. These burial efficiencies for reactive $\mathrm{P}$ are in the range found for oxic Arabian Sea sediments (Schenau and de Lange, 2001) and are much higher than those during sapropel times ( $\sim 7$ to $15 \%$; Table 3$)$.

\subsection{Role of $P$ in Sapropel $S 1$ Formation}

Enhanced regeneration of $\mathrm{P}$ at the seafloor can only have played a role in sapropel formation if it resulted in a significant increase in water column $\mathrm{HPO}_{4}^{2-}$ concentrations and if there was sufficient vertical mixing to allow the transport of the $\mathrm{HPO}_{4}^{2-}$ from the deep-water to the photic zone (see model calculations of Van Cappellen and Ingall, 1994).

The formation of sapropel S1 most likely occurred in an antiestuarine type of circulation, which was somewhat weakened relative to that of the present day (Rohling, 1994; Myers et al., 1998; Stratford et al., 2000). Vertical mixing was reduced but not completely absent (e.g., Murat and Got, 2000; Stratford et al., 2000). A tentative P budget for the eastern Mediterranean before anthropogenic perturbation is presented in Figure 8A. Sediment $\mathrm{P}$ burial was estimated from the average total $\mathrm{P}$ flux after S1 at two-low sedimentation (Table 2) and a high-sedimentation site in the southern Aegean Sea (present day: $\sim 1530$ $\mu \mathrm{mol} \mathrm{m}{ }^{-2} \mathrm{yr}^{-1}$; data not shown) and the area of the eastern Mediterranean $\left(1.6 \times 10^{12} \mathrm{~m}^{2}\right.$; Sarmiento et al., 1988), assuming that high and low sedimentation areas each cover $50 \%$ (based on water depths; Emelyanov and Shimkus, 1986). In this type of circulation, net outflow of P occurs at the Strait of Sicily as a result of the import of nutrient-depleted surface waters and the export of nutrients in the intermediate water. This net outflow is assumed to be equal to $3.9 \times 10^{12} \mathrm{mmol} \mathrm{yr}^{-1}$ (Béthoux, 1981). Assuming steady state-that is, no gain in $\mathrm{P}$ concentrations in the water column-the sum of the atmospheric and riverine inputs should be equal to $5.4 \times 10^{12} \mathrm{mmol}$ $\mathrm{yr}^{-1}$.

The $\mathrm{P}$ budget during formation of sapropel $\mathrm{S} 1$ times will 

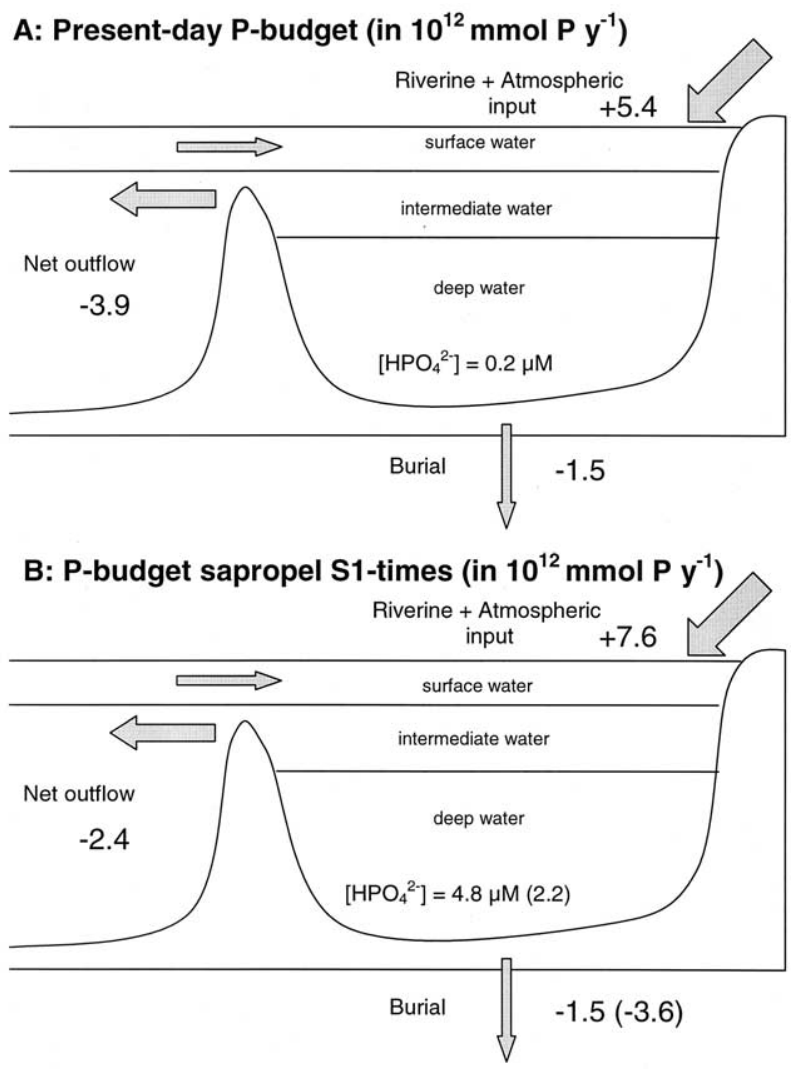

Fig. 8. Tentative P budget for the eastern Mediterranean Sea (A) at present and (B) during sapropel formation. Values between brackets hold for the case if no enhanced regeneration occurred.

have been significantly different (Fig. 8B). Sediment total $\mathrm{P}$ burial is estimated to have been similar (low sedimentation sites: Table 2; high sedimentation site: $\sim 1650 \mu \mathrm{mol} \mathrm{m}^{-2} \mathrm{yr}^{-1}$; data not shown). Terrestrial input of $\mathrm{P}$ is estimated to have increased by $\sim 40 \%$ (Sarmiento et al., 1988). The decrease in net outflow of water at the Strait of Sicily due to the more sluggish circulation will have been partly compensated by higher $\mathrm{P}$ concentrations in the outflowing water. Here, the outflow is estimated as $60 \%$ of the net outflow for the presentday circulation (Stratford et al., 2000). The imbalance in the P-budget will have resulted in an accumulation of $\mathrm{P}$ in the water column during sapropel times of $3.7 \times 10^{12} \mathrm{mmol} \mathrm{yr}^{-1}$. After a period of $3000 \mathrm{yr}$, and assuming a volume of the deep water in the eastern Mediterranean Sea of $2.4 \times 10^{15} \mathrm{~m}^{3}$, this will have resulted in a $\mathrm{HPO}_{4}^{2-}$ concentration of $4.8 \mu \mathrm{M}$ - that is, an increase by a factor of 24 relative to the preanthropogenic $\mathrm{P}$ deep-water concentration of $0.2 \mu \mathrm{M}$.

If no enhanced regeneration of $\mathrm{P}$ occurred during sapropel formation and the burial efficiency of $\mathrm{P}_{\text {org }}$ were equal to that of $\mathrm{C}_{\text {org }}$, the average total P burial at stations BC19 and SL114 would be equal to 576 and $519 \mu \mathrm{mol} \mathrm{m}{ }^{-2} \mathrm{yr}^{-1}$, respectively. This means that the total $\mathrm{P}$ burial would increase by, on average, a factor 2.4 (see Table 2). Assuming this holds for the entire eastern Mediterranean basin, the corresponding net accumulation of $\mathrm{HPO}_{4}^{2-}$ in the water column would have been $1.6 \times 10^{12} \mathrm{mmol} \mathrm{yr}^{-1}$. This would result in a deep-water $\mathrm{HPO}_{4}^{2-}$ concentration of $2.2 \mu \mathrm{M}$ instead of $4.8 \mu \mathrm{M}$ after 3000 yr (Fig. 8B). Our results demonstrate that enhanced regeneration of $\mathrm{P}$ relative to $\mathrm{C}$ has a large impact on water column $\mathrm{HPO}_{4}^{2-}$ concentrations and should be included in models of nutrient cycling and water circulation in sapropel times. Provided vertical transport to the photic zone was sufficient, the more efficient recycling of $\mathrm{P}$ may have played a key role in maintaining elevated primary productivity during sapropel S1 formation.

\section{CONCLUSIONS}

The results of solid-phase $\mathrm{P}$ speciation for sediments from the deep basin of the eastern Mediterranean Sea indicate enhanced benthic regeneration of $\mathrm{P}$ relative to $\mathrm{C}$ during formation of the most recent eastern Mediterranean sapropel S1. This is largely due to the enhanced release of $\mathrm{P}$ from organic matter in the absence of oxic conditions in the bottom waters. Release of $\mathrm{P}$ from $\mathrm{Fe}$-oxides was a relatively minor source of dissolved $\mathrm{P}$. Increased burial of biogenic Ca-P (i.e., phosphatic fish debris) may partly compensate the enhanced release from organic matter and Fe-oxides. Reconstruction of the sedimentary $\mathrm{P}$ cycle during sapropel S1 times additionally indicates the following: (1) enhanced benthic release of $P$ relative to the present day; (2) a lack of CFA formation due to relatively low porewater $\mathrm{HPO}_{4}^{2-}$ concentrations; and (3) a low burial efficiency for reactive $\mathrm{P}$ in the anoxic sediment of $\sim 7$ to $15 \%$. The presentday $\mathrm{P}$ cycle deduced from both solid-phase and pore-water data is characterized by the following: (1) rapid degradation of organic matter and release of $\mathrm{HPO}_{4}^{2-}$ at the sediment-water interface; (2) sorption of upward-diffusing $\mathrm{HPO}_{4}^{2-}$ from below the sapropel to $\mathrm{Fe}$ oxides at the oxidation front at the top of the sapropel; (3) efficient retention of organic $\mathrm{P}$ by aerobic organisms during oxidation of the sapropel; and (4) a high burial efficiency for reactive $\mathrm{P}$ in the oxic sediment of $\sim 64$ to $77 \%$. Budget calculations for the eastern Mediterranean Sea demonstrate that both the weakening of the antiestuarine circulation and the enhanced regeneration of $\mathrm{P}$ contributed to a significant increase in deep-water $\mathrm{HPO}_{4}^{2-}$ concentrations during sapropel S1 times. This shows that-provided that sufficient vertical mixing occurred-enhanced regeneration of $\mathrm{P}$ could play an important role in sapropel formation.

Acknowledgments-M. S. Principato is acknowledged for providing the sieve fractions for the fish debris counts. T. Van Wijk, H. de Waard, and A. Gebhardt are thanked for their contribution to the laboratory analyses. J. van Ooijen and G. Nobbe performed the onboard nutrient analyses. We are grateful to G. J. Reichart for his assistance in the microscopic identification of the fish debris. We thank P. Van Cappellen, G. Filipelli, K. C. Ruttenberg, and E. Ingall for valuable comments on the article in manuscript. We are grateful to the shipboard parties of the RV Logachev and Marion Dufresne cruises for their contribution to the sample collection. The cruise with RV Logachev was financially supported by NWO (SMILE/PASS2). This is publication 20010302 of the NSG. This work was supported by the European Union Marine Science and Technology Programme, contract MAS3CT97-0137.

Associate editor: D. J. Burdige

\section{REFERENCES}

Arthur M. A., Dean W. E., Neff E. D., Hay B. J., King J., and Jones G. (1994) Varve calibrated records of carbonate and organic carbon 
accumulation over the last 2000 years in the Black Sea. Global Biogeochem. Cycles 8, 195-217.

Arthur M. A. and Dean W. E (1998) Organic-matter production and preservation and evolution of anoxia in the Holocene Black Sea. Paleoceanography 13, 395-411.

Atlas E. and Pytkowicz R. M. (1977) Solubility behavior of apatites in seawater. Limnol. Oceanogr. 22, 290-300.

Banse K. (1968) Hydrography of the Arabian Sea Shelf of India and Pakistan and effects on demersal fishes. Deep-Sea Res. 15, 45-79.

Berland B. R., Bonin D. J., and Maestrini S. Y. (1980) Azote ou phosphore? Considerations sur le "paradox nutrionnel" de la mer Mediterranee. Oceanol. Acta 3, 135-142.

Béthoux J. P. (1981) Le phosphore et l'azote en Mediterranee, bilans et fertilite potentielle. Mar. Chem. 10, 141-158.

Béthoux J. P. (1989) Oxygen consumption, new production, vertical advection and environmental evolution in the Mediterranean Sea. Deep-Sea Res. 36, 769-781.

Bosch H.-J., Sinnighe Damsté J. S., and de Leeuw J. W. (1998) Molecular palaeontology of eastern Mediterranean sapropels: Evidence for photic zone euxinia. In Proc. ODP Sci. Res.(eds. A. H. F. Robertson, K.-C. Emeis, C. Richter, and A. Camerlenghi), Vol. 160, pp. 285-295.

Bruins H. J. and Van der Plicht J. (1996) The Exodus enigma. Nature 382, 213-214.

Calvert S. E., Nielsen B., and Fontugne M. R. (1992) Evidence from nitrogen isotope ratios for enhanced productivity during formation of eastern Mediterranean sapropels. Nature 359, 223-225.

Canfield D. E. (1989) Sulfate reduction and oxic respiration in marine sediments: Implications for organic carbon preservation in euxinic environments. Deep-Sea Res. 36, 121-138.

Caraco N. F., Cole J. J., and Likens G. E. (1989) Evidence for sulphate-controlled phosphorus release from sediments of aquatic systems. Nature 341, 316-318.

Collins M., Nielsen-Marsh C., Smith C., and Gerneay A. (1999) An overview of the scientific study of bone. In The Degradation of Bone as an Indicator in the Deterioration of the European Archeological Property (eds. H. Kars and E. A. K. Kars), Appendix C1, pp. 1-79. Annual Report 1. EC Project ENV4-CT98-0712.

Colman A. S., Mackenzie F. T., and Holland H. D. (1997) Comment on "Redox stabilization of the atmosphere and oceans and marine productivity." Science 275, 406-408.

Colman A. S. and Holland H. D. (2000) The global diagenetic flux of phosphorus from marine sediments to the oceans: Redox sensitivity and the control of atmospheric oxygen levels. In Marine Authigenesis: From Global to Microbial,pp. 53-75. Special Publication 66. SEPM (Society for sedimentary Geology).

Curtis P. J. (1989) Effects of hydrogen ion and sulphate on the phosphorus cycle of a Precambrian Shield lake. Nature 337, 156-158.

de Lange G. J., Van Os B., Pruysers P. A., Middelburg J. J., Castradori D., Van Santvoort P., Müller P. J., Eggenkamp H., and Prahl F. G. (1994) Possible early diagenetic alteration of palaeo proxies. In Carbon Cycling in the Glacial Ocean: Constraints on the Ocean's Role in Global Change (eds. R. Zahn et al.), pp. 225-258. NATO ASI Series Vol. 117. Springer-Verlag.

DeVries T. J. and Pearcy W. G. (1982) Fish debris in sediments of the upwelling zone off central Peru: A late Quaternary record. Deep-Sea Res. 25, 431-445.

Eijsink L. M., Krom M. D., and de Lange G. J. (1997) The use of sequential extraction techniques for sedimentary phosphorus in eastern Mediterranean sediments. Mar. Geol. 139, 147-155.

Einsele W. (1936) Über die Beziehungen des Eisenkreislaufs zum Phosphatkreislauf im eutrophen See. Arch. Hydrobiol. 29, 664-686.

Emeis K.-C., Robertson A. H. F., Richter C., et al., eds. (1996) Proc. ODP Init. Rep. 160

Emelyanov E. M. and Shimkus K. M. (1986) Geochemistry and Sedimentology of the Mediterranean Sea. Reidel. Proceedings of the Ocean Drilling Program Initial Report.

Filipelli G. M. (1997) Controls on phosphorus concentration and accumulation in oceanic sediments. Mar. Geol. 139, 231-240.

Froelich P. N., Bender M. L., Luedtke N. A., Heath G. R., and DeVries T. (1982) The marine phoshorus cycle. Am. J. Sci. 282, 474-511.

Gächter R., Meyer J. S., and Mares A. (1988) Contribution of bacteria to release and fixation of phosphorus in lake sediments. Limnol. Oceanogr. 33, 1542-1558.

Grasshoff K. (1983) Methods of Seawater Analysis. Verlag Chemie.

Hensen C., Landenberger H., Zabel M., and Schulz H. D. (1998) Quantification of diffusive benthic fluxes of nitrate, phosphate, and silicate in the southern Atlantic Ocean. Global Biogeochem. Cycles 12, 193-210.

Hilgen F. J. (1991) Astronomical calibration of Gauss to Matuyama sapropels in the Mediterranean and implication for the geomagnetic polarity time scale. Earth Planet. Sci. Lett. 104, 226-244.

Howell M. W. and Thunell R. C. (1992) Organic carbon accumulation in Bannock Basin: Evaluating the role of productivity in the formation of eastern Mediterranean sapropels. Mar. Geol. 103, 461-471.

Ingall E. D., Bustin R. M., and Van Cappellen P. (1993) Influence of water column anoxia on the burial and preservation of carbon and phosphorus in marine shales. Geochim. Cosmochim. Acta 57, 303316.

Ingall E. and Jahnke R. (1994) Evidence for enhanced phosphorus regeneration from marine sediments overlain by oxygen depeleted waters. Geochim. Cosmochim. Acta 58, 2571-2575.

Ingall E. D. and Jahnke R. A. (1997) Influence of water-column anoxia on the elemental fractionation of carbon and phosphorus during sediment diagenesis. Mar. Geol. 139, 219-229.

Krom M. D. and Berner R. A. (1980) The diffusion coefficient of sulfate, ammonium and phosphate ions in anoxic marine sediments. Limnol. Oceanogr. 25, 327-337.

Krom M. D., Kress N., and Brenner S. (1991) Phosphorus limitation of primary productivity in the eastern Mediterranean Sea. Limnol. Oceanogr. 36, 424-432.

Lourens L. J., Antonarakou A., Hilgen F. J., Van Hoof A. A. M., Vergnaud-Grazzini C., and Zachariasse W. J. (1996) Evaluation of the Plio-Pleistocene astronomical timescale. Paleoceanography 11, 391-413.

Lucotte M., Mucci A., Hillaire-Marcel C., and Tran S. (1994) Early diagenetic processes in deep Labrador Sea sediments: Reactive and nonreactive iron and phosphorus. Can. J. Earth Sci. 31, 14-27.

Lückge A., Ercegovac M., Strauss H., and Littke R. (1999) Early diagenetic alteration of organic matter by sulfate reduction in Quaternary sediments from the northeastern Arabian Sea. Mar. Geol. 158, $1-13$.

McManus J., Berelson W. M., Coale K. H., Johnson K. S., and Kilgore T. E. (1997) Phosphorus regeneration in continental margin sediments. Geochim. Cosmochim. Acta 61, 2891-2907.

Mercone D., Thomson J., Croudace I. W., Siani G., Paterne M., and Troelstra S. (2000) Duration of. S1, the most recent sapropel in the eastern Mediterranean Sea, as indicated by accelerator mass spectrometry radiocarbon and geochemical evidence. Paleoceanography 15, 336-347.

Mercone D., Thomson J., Abu-Zied R. H., Croudace I. W., and Rohling E. J. (2001) High-resolution geochemical and micropaleontological profiling of the most recent eastern Mediterranean sapropel. Mar. Geol., 177, 25-44.

Mortimer C. H. (1941) The exchange of dissolved substances between mud and water in lakes. Int. J. Ecol. 30, 280-329.

Murat A. and Got H. (2000) Organic carbon variations of the eastern Mediterranean Holocene sapropel: A key for understanding formation processes. Palaeogeogr. Palaeoclimatol. Palaeoecol. 158, $241-$ 257.

Myers P. G., Haines K., and Rohling E. J. (1998) Modeling the paleocirculation of the Mediterranean: The last glacial maximum and the Holocene with emphasis on the formation of sapropel S1. Paleoceanography 13, 586-606.

Nijenhuis I. A., Bosch H.-J., Sinnighe Damsté J. S., Brumsack H.-J., and de Lange G. J. (1999) Organic matter and trace element rich sapropels and black shales: A geochemical comparison. Earth Planet. Sci. Lett. 169, 277-290.

Passier H. F., Middelburg J. J., van Os B. J. H., and de Lange G. J. (1996) Diagenetic pyritisation under eastern Mediterranean sapropels caused by downward sulphide diffusion. Geochim. Cosmochim. Acta 60, 751-763.

Passier H. F., Middelburg J. J., de Lange G. J., and Böttcher M. E. (1997) Pyrite contents, microtextures, and sulphur isotopes in rela- 
tion to formation of the youngest eastern Mediterranean sapropel. Geology 25, 519-522.

Passier H. F. and de Lange G. J. (1998) Sedimentary sulfur and iron chemistry in relation to the formation of eastern Mediterranean sapropels. In Proc. ODP Sci. Res.(eds. A. H. F. Robertson, K.-C. Emeis, C. Richter, and A. Camerlenghi), Vol. 160, pp. 249-259.

Passier H. F., Middelburg J. J., de Lange G. J., and Böttcher M. E. (1999) Modes of sapropel formation in the eastern Mediterranean: Some constraints based on pyrite properties. Mar. Geol. 153, 199 219.

Pruysers P. A., de Lange G. J., and Middelburg J. J. (1991) Geochemistry of eastern Mediterranean sediments: Primary sediment composition and diagenetic alterations. Mar. Geol. 100, 137-154.

Rohling E. J. (1994) Review and new aspects concerning the formation of eastern Mediterranean sapropels. Mar. Geol. 122, 1-28.

Rossignol-Strick M., Nesterhoff W., Olive P., and Vergnaud-Grazzini C. (1982) After the deluge: Mediterranean stagnation and sapropel formation. Nature 295, 105-110.

Ruttenberg K. C. (1992) Development of a sequential extraction method for different forms of phosphorus in marine sediments. Limnol. Oceanogr. 37, 1460-1482.

Sarmiento J. L., Herbert T., and Toggweiler J. R. (1988) Mediterranean nutrient balance and episodes of anoxia. Global Biogeochem. Cycles. $2,427-444$.

Schenau S. J. and de Lange G. J. (2000) A novel chemical method to quantify fish debris in marine sediments. Limnol. Oceanogr. 45, 963-971.

Schenau S. J., Slomp C. P., and de Lange G. J. (2000) Phosphogenesis and active phosphorite formation in sediments from the Arabian Sea oxygen minimum zone. Mar. Geol. 169, 1-20.

Schenau S. J. and de Lange G. J. (2001) Phosphorus regeneration versus burial in sediments of the Arabian Sea. Mar. Chem. 75, 201-217.

Slomp C. P., Epping E. H. G., Helder W., and van Raaphorst W. (1996) A key role for iron-bound phosphorus in authigenic apatite formation in North Atlantic continental platform sediment. J. Mar. Res. 54, $1179-1205$.

Slomp C. P., Malschaert J. F. P., and van Raaphorst W. (1998) The role of sorption in sediment-water exchange of phosphate in North Sea continental margin sediments. Limnol. Oceanogr. 43, 832-846.

Stratford K., Williams R. G., and Myers P. G. (2000) Impact of the circulation on sapropel formation in the eastern Mediterranean. Global Biogeochem. Cycles 14, 683-695.

Strickland T. R. and Parsons J. D. (1972) A Practical Handbook of Seawater Analysis, 2nd ed. Bull. Fish. Res. Board Can., Vol. 167.
Stuiver M., Reimer P. J., Bard E., Beck J. W., Burr G. S., Hughen K. A., Kromer B., McCormac F. G., van der Plicht J., and Spurk M. (1998) INTCAL98 radiocarbon age calibration, 24,000-0 cal BP. Radiocarbon 40, 1041-1083.

Suess E. (1981) Phosphate regeneration from sediments of the Peru continental margin by dissolution of fish debris. Geochim. Cosmochim. Acta 45, 577-588.

Thomson J., Higgs N. C., Wilson T. R. S., Croudace I. W., de Lange G. J., and van Santvoort P. J. M. (1995) Redistribution and geochemical behaviour of redox-sensitive elements around $\mathrm{S} 1$, the most recent eastern Mediterranean sapropel. Geochim. Cosmochim. Acta 59, 3487-3501.

Thomson J., Mercone D., de Lange G. J., and van Santvoort P. J. M. (1999) Review of recent advances in the interpretation of eastern Mediterranean sapropel S1 from geochemical evidence. Mar. Geol. 153, 77-89.

Thunell R. C. and Williams D. F. (1989) Glacial-Holocene salinity changes in the Mediterranean Sea in relation to the evolution of late neogene climates. Nature 338, 493-496.

Tunnicliffe V., O'Connell J. M., and McQuoid M. R. (2001) A. Holocene record of marine fish remains from the Northeastern $\mathrm{Pa}-$ cific. Mar. Geol. 174, 197-210.

Van Cappellen P. and Berner R. A. (1988) A mathematical model for the early diagenesis of phosphorus and fluorine in marine sediments: Apatite precipitation. Am. J. Sci. 288, 289-333.

Van Cappellen P. and Ingall E. D. (1994) Benthic phosphorus regeneration, net primary production, and ocean anoxia: A model of the coupled marine biogeochemical cycles of carbon and phosphorus. Paleoceanography 9, 677-692.

Van Cappellen P. and Ingall E. D. (1996) Redox stabilization of the atmosphere and oceans by phosphorus-limited marine productivity. Science 271, 493-496.

Van Cappellen P. and Ingall E. D. (1997) Response to comment "Redox stabilization of the atmosphere and oceans and marine productivity" by A. S. Colman, F. T. Mackenzie, and H. D. Holland. Science 275, 407-408.

Van der Borg K., Alderliesten C., Houston C. M., de Jong A. F. M., and van Zwol N. A. (1987) Acceleration Mass Spectrometry with 14C and 10Be in Utrecht. Nucl. Instr. Methods B29, 143.

Van Santvoort P. J. M., de Lange G. J., Thomson J., Cussen H., Wilson T. R. S., Krom M. D., and Ströhle K. (1996) Active post-depositional oxidation of the most recent sapropel (S1) in sediments of the eastern Mediterranean Sea. Geochim. Cosmochim. Acta 60, 4007-4024. 